\title{
Analysing the discursive strategies in the narratives of victims of an Egyptian sex predator: a corpus-assisted Discourse Historical approach
}

\author{
Dr Wesam M. A. Ibrahim \\ Associate Professor of Linguistics \\ Department of Foreign Languages, Faculty of Education, \\ Tanta University, Egypt
}

\begin{abstract}
Stories about a young man raping and sexually harassing a hundred women and minor girls flooded Egyptian social media since the beginning of July 2020. 100 narratives reporting this man's verbal and physical abuse of his victims were posted on an Instagram account called @assaultpolice. The story of this person who was dubbed, the 'Sex Predator', trended on Twitter and Instagram, and was then picked up by many Egyptian talk shows. The focus of social media and TV channels on the events of this story motivated the Egyptian National Council for Women (NCW) to interfere and stand by the victims by reporting the case to the Prosecution Council. This created a controversy in such a conservative society as Egypt which has always tended to blame the victim of any kind of sexual abuse. This paper uses a corpusassisted Discourse Historical approach to analyse these narratives and explore how they construct the sexual aggressor and the victims.
\end{abstract}

\section{Keywords}

Sexual violence narratives, Egyptian sex predator, keywords, the discourse historical approach 


\section{مجلة وادي النيل للاراسات والبحوث الإنسانية والاجتماعية والتربوية (مجلة علمية محكمة)}

(ISSN : 2536 - 9555)

\section{تحليل استراتيجيات الخطاب في قصص ضحايا ذئب بشري مصري: مدخل خطابي تاريخي مدعوم بعلم المخزونات اللغويـة}

\section{د/ وسام عحم عبد الخالق إبراهيم}

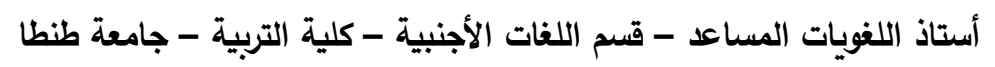

الملخص:

في بداية شهر يوليو • ·. · فاضت وسائل التواصل الاجتماعي المصرية

بقصص حول شاب قد قام بارتكاب جرائم اغتصاب وتحرش جنسي في حق مئات النساء والفتيات القاصرات. وقد تم نشر مائة قصة حول جرائم هذا الثاب من بن انتهاكات جسية ولفظية لضحاياه علي حساب في الانستجرام يسمي اسوولتبوليس. وقد أصبحت قصة هذا الثاب الذي تم نعته بـ "الأئب البشري" تريند علي وسائل التواصل الاجتماعي أي أنها لاقت رواجا كبيرا وتلقفتها البرامج الحوارية بالتليفزيون المصري. وقد دفع الاهتمام الذي قدمته وسائل التواصل الاجتماعي والقنوات التليفزيونية لهذا الموضوع إلي قيام المجلس القومي للمرأة بالتدخل ومساندة الضحايا وتبليغ النيابة العامة بهذه القضية. وقد أثار هذا لهاب الموضوع جدلا كبيرا في المجتمع المصري المحافظ بطبيعته والذي يميل غالبا إلي لوم ضحايا الانتهاكات الجنسية. يستخدم هذا البحث مدخلا خطابيا تاريخيا مدعوما بعلم المخزونات اللغوية في تحليل هذه القصص واستكثاف كيفية تصوير كلمات مفتاحية الجنسي والضحايا في النص. قصص العنف الجنسي، الذئب البشري المصري، الكلمات المفتاحية، الاستراتيجيات الخطابية، المدخل الخطابي التاريخي. 
Analysing the discursive strategies in the narratives of victims of an Egyptian sex predator: a corpus-assisted Discourse Historical approach Dr Wesam M. A. Ibrahim

مجلة وادي النيل للاراسات والبحوث الإنسانية والاجتماعية والتربوية (مجلة علمية محكمة)

\section{Introduction}

An Egyptian female student at the American University in Cairo accused a fellow student of sexually harassing her and her friends in a post on the RATE AUC PROFESSORS ${ }^{1}$ Facebook group in 2018. Her post, which gathered thousands of comments, was surprisingly deleted by the group's administrators two years later at the end of June 2020. Following the deletion of the post, on $1^{\text {st }}$ July 2020, many other girls shared their stories and experiences with the same guy (henceforth, I will call him ABZ, using his initials), which dated from as far back as 2016, on two key Instagram profiles that attracted widespread attention: @,skhodirr (writer and poet Sabah Khodir's personal profile) and (a) assaultpolice (an account initiated to gather evidence against ABZ). Two hashtags related to the allegations were top trending in Egypt from the start of July 2020. The stories report incidents of rape, sexual assault and sexual harassment allegedly committed by ABZ during both his studies at AUC in Cairo, between 2016 and 2018, and his further studies at the EU Business School in Barcelona since 2018. The Instagram account ${ }^{2} @$ assaultpolice, which had at the end of July 2020 up to 172k followers, collected evidence against ABZ who was claimed to have harassed and assaulted over 100 girls. The stories posted on@assaultpolice (which include both personal accounts of physical or internet harassment and screenshots of separate conversations between a number of women and a person alleged to be ABZ) show various threats and aggressive behaviour and have been classified into six sections: odd behavior, real-life harassment, online harassment, physical assault, blackmail and threat and AU Barcelona. The stories are written in a mix of English and Arabic (Arabic words written using English letters). The victims' use of English language in their narratives, with only a few words in Arabic written also in English letters, may be explained as follows. It can be seen as a

${ }^{1} \mathrm{https}: / / \mathrm{www}$. facebook.com/groups/rate.auc.prof

${ }^{2}$ https://www.instagram.com/assaultpolice/ 
(ISSN : 2536 - 9555)

defensive strategy against Egyptian culture which sees sexual abuse as bringing shame on the victim and her family. Hence, such narratives, which usually tend to be suppressed, may be described as what Coupland and Coupland (1997: 117) have called 'discourses of the unsayable'. Probably, the victims could not recount the abuse they suffered in their native language (Arabic) because they would be stigmatized by the community; so, they may have delivered their narratives in English to detach and protect themselves from the judgmental culture they belong to. In addition, the shared background of the victims - who belong to rich families, live in luxurious residential compounds, and study at international schools and universities - has to be taken into consideration. It should be noted that most victims may have a native-like competence in English, so this hybrid language may be the kind of language they use in their everyday life.

$\mathrm{ABZ}$ was accused of using various tactics to lure his victims or to otherwise force them to do what he wanted. The victims claimed that he created multiple social media accounts which he used to message them privately and repeatedly ask for their numbers and for 'inappropriate favours' ${ }^{3}$. He also used to manipulate them emotionally into meeting him or chatting with him using social media by threatening to self-harm and commit suicide. Then, he would blackmail them by using fake and/or real nude shots, threatening to share them and tell stories about their sexual encounters with their respective families and friends.

According to Egyptian Streets ${ }^{4}$, ABZ's name remains trending on Twitter as at the date and time of publication $\left(2^{\text {nd }}\right.$ July 2020), with stories and a petition ${ }^{5}$ on Change.org being shared

3 https://egyptianstreets.com/2020/07/02/egypts-silent-victims-manaccused-of-rape-harassment-by-50-women-exposes-rape-culture/ 4 https://egyptianstreets.com/2020/07/02/egypts-silent-victims-manaccused-of-rape-harassment-by-50-women-exposes-rape-culture/ 5 https://www.change.org/p/twitter-lock-up-ahmed-zaki-for-sexualassault?recruiter $=$ false \&recruited_by_id $=$ f20dc8c0-bbf6-11ea-a712-

371a1f28f2ab\&share_bandit_exp=skip-23203566-en-US 


\section{Analysing the discursive strategies in the narratives of victims of an Egyptian sex predator: a corpus-assisted Discourse Historical approach Dr Wesam M. A. Ibrahim \\ مجلة وادي النيل للاراسات والبحوث الإنسانية والاجتماعية والتربوية (مجلة علمية محكمة)}

around. The story was also widely covered by Egyptian TV and newspapers ${ }^{6}$. ABZ was immediately suspended from the business school at Barcelona until further investigations could be carried out. Egypt's National Council for Women (NCW), presided by Dr. Maya Morsy, responded to the issue. The NCW started to collect evidence against $\mathrm{ABZ}$ and urged women to file official complaints against him. They also publicized a hotline for complaints about sexual assaults and filed a complaint to the Prosecution Council to investigate the issue.

A few days later, $\mathrm{ABZ}$ was arrested by the Egyptian police to be interrogated by the Prosecution Council. ABZ's lawyers claimed that all the accounts of the girls accusing him were fake and that he did not know any of these girls and had not committed any of these sexual offences. They insisted that these girls had to come to the Prosecution Council and report these alleged crimes in person. Though the response to the allegations on social media had been in support of ABZ's victims, social media often does not reflect the attitudes towards rape and sexual behaviour across many segments of wider Egyptian society. Hence, the lawyers' demand that the girls reveal their true names and identities was exceptionally difficult to carry out in the Egyptian social context.

Although Egyptian authorities had introduced stricter laws and punishment against sexual harassment in 2011, 'it remains particularly difficult for women to publicly accuse men of rape, sexual assault or sexual harassment due to social and cultural views around sex and sexuality' (Egyptian Streets, $2^{\text {nd }}$ July 2020) ${ }^{7}$. Sexual assault is dramatically underreported, not only in Egypt but even in Western countries. According to the American Justice Department's analysis of violent crime in $2016, \mathbf{8 0 \%}$ of rapes and sexual assaults go unreported for reasons such as fear of

${ }^{6}$ A sample of newspapers and media coverage of the 'Egyptian Predator' story.

7 https://egyptianstreets.com/2020/07/02/egypts-silent-victims-manaccused-of-rape-harassment-by-50-women-exposes-rape-culture/ 
(ISSN : 2536 - 9555)

retaliation- not just from the perpetrator, but from society at large, and distrust of the police (Brennan Center, $4^{\text {th }}$ October 2018) ${ }^{8}$. The brutality of police questioning and rape trials, which has been dubbed by feminists as 'the second rape' may be a primary reason behind the tendency not to report sexual assault crimes, with questions such as 'Did you enjoy it? Are you a virgin? What were you wearing?' tormenting the victims (Matthews, 1994: 11). It should be noted, however, that these kinds of questions about reasons for walking alone late at night or wearing certain styles of clothing are never addressed to men (Kennedy, 1992: 114). The idea was captured by the former American President Barack Obama ${ }^{9}$, in September 2014, when he stated that

For anybody whose once normal everyday life was suddenly shattered by an act of sexual violence - the trauma, the terror, can shatter you long after one horrible attack. It lingers. You don't know where to go or who to turn to ... and people are more suspicious of what you were wearing or what you were drinking, as if it's your fault, not the fault of the person who assaulted you. We still don't condemn sexual assault as loudly as we should. We make excuses, we look the other way ... [Laws] won't be enough unless we change the culture that allows assault to happen in the first place.

In addition to the reasons mentioned above, which tend to be shared by many cultures, the situation is further complicated in Egypt since premarital sexual encounters are widely frowned upon with such a premium being placed on upholding virginity and purity.

Every female Arab child, even today, must possess that very fine membrane called a hymen, which is

${ }^{8}$ https://www.brennancenter.org/our-work/analysis-opinion/sexualassault-remains-dramatically-underreported https://www.bjs.gov/content/pub/pdf/cv16.pdf

${ }^{9}$ https://www.ncbi.nlm.nih.gov/pmc/articles/PMC6348335/ 
Analysing the discursive strategies in the narratives of victims of an Egyptian sex predator: a corpus-assisted Discourse Historical approach Dr Wesam M. A. Ibrahim

مجلة وادي النيل للاراسات والبحوث الإنسانية والاجتماعية والتربوية (مجلة علمية محكمة)

considered one of the most essential, if not the most essential, part of her body. However, the mere existence of the hymen is not in itself sufficient. This fine membrane must be capable of bleeding profusely, of letting out red blood that can be seen as a visible stain on a white bed sheet the night a young girl is married. (Alsaadawi, 2015: 51)

The deeply inculcated tradition is to associate sex with shame and virginity with honour. The honour of a woman and her family is defined by her chastity, and if she is raped she is stigmatized and no longer marriageable (Haddad, 2017).

The reputation and standing of a family may be irrevocably lost if one of the daughters loses her hymen prematurely, even though a victim of rape. This is why an incident of rape is kept a close secret and rarely divulged, thus enabling the aggressor to escape scot free. The real criminal remains safe, out of reach, protected from the hands of the law, whereas the victim who loses her virginity, the girl who loses her hymen for whatever reason, even as a result of rape, or at any age, even that of early childhood - is doomed to lose her honour for life. Her hymen is her honour and, once lost, it can never be replaced. (Alsaadawi, 2015: 39-40)

Hence, many victims feel impelled not to speak about their rape or sexual harassment for fear of being blamed by the community and having their families' honour besmirched.

\section{ABZ's Reported Crimes}

The crimes ascribed to ABZ by about 100 women and girls include physical and internet harassment, rape and blackmail. In this section, I provide a brief description of these crimes. 
(ISSN : 2536 - 9555)

Internet harassment - also known as cyberbullying, cyberstalking or online abuse - can be defined as the 'use of the Internet to harass, threaten, or maliciously embarrass' (The Canadian Centre for Occupational Health and Safety, $\mathrm{CCOHS}^{10}$ ). According to the Harvard Business Review ( $3^{\text {rd }}$ June 2020), this kind of abuse began with the advent of the internet itself, and with time is getting progressively ever more pervasive and growing. A study conducted by the Pew Research Center in 2017 found that 'more than $40 \%$ of Americans have experienced online abuse, and more than $60 \%$ have witnessed it ${ }^{11}$. The frequency of online abuse is likely to be the same worldwide in spite of the absence of statistics in many countries. The term, according to CCOHS, covers a range of illegal behaviours, such as:

1. Sending unsolicited and/or threatening e-mail.

2. Encouraging others to send the victim unsolicited and/or threatening e-mail or to overwhelm the victim with e-mail messages.

3. Sending viruses by e-mail (electronic sabotage).

4. Spreading rumours.

5. Making defamatory comments about the victim online.

6. Sending negative messages directly to the victim.

7. Impersonating the victim online by sending an inflammatory, controversial or enticing message which causes others to respond negatively to the victim.

8. Harassing the victim during a live chat.

9. Leaving abusive messages online, including social media sites.

10. Sending the victim pornography or other graphic material that is knowingly offensive.

11. Creating online content that depicts the victim in negative ways.

(CCOHS website, July 2020)

${ }_{11}^{10}$ https://www.ccohs.ca/oshanswers/psychosocial/cyberbullying.html

$11 \mathrm{https}: / / \mathrm{hbr}$.org/2020/06/youre-not-powerless-in-the-face-of-onlineharassment 
Analysing the discursive strategies in the narratives of victims of an Egyptian sex predator: a corpus-assisted Discourse Historical approach Dr Wesam M. A. Ibrahim

مجلة و ادي النيل للاراسات والبحوث الإنسانية والاجتماعية والتربوية (مجلة علمية محكمة)

ABZ had allegedly committed at least four offensive behaviours on the CCOHS list provided above, including: Sending unsolicited and/or threatening e-mail; Sending negative messages directly to the victim; Harassing the victim during a live chat; and Sending the victim pornography or other graphic material that is knowingly offensive.

Blackmail involves a threat to reveal embarrassing, harmful, and/or shameful information about a person, unless that person meets certain demands either paying money to the blackmailer or performing other actions which may not be legal ${ }^{12}$. The advent and subsequent growth of the Internet has also led to an overlap between blackmail and cybercrime. The offence of blackmail consists of a demand made with an unwarranted menace in order to obtain some gain for the self and/or cause loss to another ${ }^{13}$. ABZ was accused of threatening various girls he would share fake nude images, chat messages and videotaped encounters with their family members unless they satisfied his demands.

Harassment, in general terms, according to the Canadian Human Rights Commission, occurs when someone 'makes unwelcome remarks or jokes', 'threatens or intimidates' another person because of his/ her race, religion, sex, age, disability or any other of the grounds of discrimination; or makes 'unwelcome physical contact ... such as touching, patting, or pinching ${ }^{14}$. As for sexual harassment, it 'includes unwelcome sexual advances, requests for sexual favors, and other verbal or physical harassment of a sexual nature in the workplace or learning environment,

${ }^{12} \mathrm{https}$ ///www.hg.org/extortion.html https://www.justia.com/criminal/offenses/white-collar-crimes/blackmail/ ${ }^{13} \mathrm{https}$ ://uk.practicallaw.thomsonreuters.com/w-007-

7415 transitionType $=$ Default\&contextData $=($ sc. Default $) \&$ firstPage $=$ true \&bhcp $=1$

${ }^{14} \mathrm{https}$ ://www.chrc-ccdp.gc.ca/eng/content/what-harassment-1 
(ISSN : 2536 - 9555)

according to the Equal Employment Opportunity Commission, ${ }^{15}$. ABZ was accused of sexually harassing many of the victims.

Rape can be seen as 'a crime of power and violence in which sex is the weapon' (Holmes and Holmes, 2002: 139); 'the sexual expression of power and anger' (Groth, 1979: 2); 'an act of terrorism and torture within a systemic context of group subjection, like lynching' (MacKinnon, 1989: 172); and 'a violent crime against the person and not as a specifically sexual encounter' (Notman and Nadelson, 1980: 135). ABZ is accused of raping two women and this offence is probably the most serious among all his crimes.

There are many studies of sexual harassment particularly in the workplace (see Fitzgerald et al., 1988; Fitzgerald and Cortina, 2017; Hajdin, 1994; Hajdin, 1997; Holland and Cortina, 2016; Johnson, Widnall and Benya, 2018; Konik and Cortina, 2008; Leskinen, Cortina and Kabat, 2011; Rabelo and Cortina, 2014; Seagrave, 2013). Other studies deal with cultural and linguistic perspectives on it (see Baugh, 2018; Gelfand, Fitzgerald and Drasgow, 1995; Tyler and Boxer, 1996). Recently, academic attention has been dedicated to studying the language of harassment on social media (see Hosseinmardi et al., 2015; Mangaonkar, Hayrapetian and Raje, 2015; Nobata et al., 2016; Rezvan et al., 2020). This study contributes to the last group since it deals with narratives of sexual harassment and violence published on social media, and more particularly, Instagram.

\section{Theoretical Approaches}

\section{Discourse Historical Approach (DHA)}

Language does not just describe, represent or reflect an external reality but constructs our experience of the world (Willig, 1999). 'Language users actively engage in text and talk not only as speakers, writers, listeners or readers, but also as members of

\footnotetext{
${ }^{15} \mathrm{https}: / /$ www.rainn.org/articles/sexual-harassment
} 


\section{Analysing the discursive strategies in the narratives of victims of an Egyptian sex predator: a corpus-assisted Discourse Historical approach Dr Wesam M. A. Ibrahim}

مجلة وادي التيل للاراسات والبحوث الإنسانية والاجتماعية والتربوية (مجلة علمية محكمة)

social categories, groups, professions, organizations, communities, societies or cultures' (van Dijk, 1997: 3). The premise that the social world is constructed via language has led to the emergence of Critical Discourse Analysis (CDA). Various definitions of CDA can be found in the literature (cf. Caldas-Coulthard and Coulthard, 1996; Fairclough, 1992; Fairclough, 2010; Fairclough and Wodak, 1997; Fairclough, Mulderrig and Wodak, 2011; Locke, 2004; Machin and Mayr, 2012; van Dijk, 2001; van Dijk, 2008; van Leeuwen, 2005; van Leeuwen, 2008; Weiss and Wodak, 2007; Wodak and Chilton, 2005; Wodak, 2011a; Wodak, 2011b; Wodak and Meyer, 2009). CDA can be defined as 'a type of discourse analytical research that primarily studies the way social power abuse, dominance, and inequality are enacted, reproduced, and resisted by text and talk in the social and political context' (van Dijk, 2001: 352); and, as being fundamentally interested in analyzing opaque as well as transparent structural relationships of dominance, discrimination, power and control as manifested in language (Wodak and Meyer, 2009: 10).

The definition and function of CDA are concurrent and integrated. Hence, the main goal of CDA is to 'investigate critically social inequality, as it is expressed, signaled, constituted, legitimized and so on by language use' (Wodak and Meyer, 2009: 10). CDA is "not interested in investigating a linguistic unit per se but in studying social phenomena which are necessarily complex and thus require a multidisciplinary and multi-methodical approach' (Wodak and Meyer, 2009: 2). It is eclectic and interdisciplinary since the complex relations between discourse and society cannot be analyzed fully without blending linguistic and social approaches (Wodak and Weiss, 2005: 124).

This study uses the Discourse-Historical Approach (DHA), which is a strand of CDA (Reisigl and Wodak, 2001; Reisigl and Wodak, 2009; Wodak, 1986; Wodak, 2001; Wodak, 2011b; Wodak, 2015). DHA shares the same principles of CDA since both 'aim to reveal and demystify power structures from the perspective 
(ISSN : 2536 - 9555)

of those who suffer' (Wodak, 2008: 2). This study deals with the narratives of victims of rape, sexual harassment and blackmail, being recounted from 'the perspective of those who suffer'. It explores the discursive strategies, as outlined by Reisigl and Wodak (2009: 104) and Wodak (2015: 8-11), which are involved in constructions of identities (the victims), of the 'other' (ABZ, the sexual assaulter), and of situations and processes in general (sexual harassment, rape, blackmail and so on).

DHA has identified several discursive strategies that are common within discourse (Reisigl and Wodak, 2001; Reisigl and Wodak, 2009; Wodak, 2015). This study uses a selection of these strategies, as shown in Table 1 below, to analyze the narratives of rape and sexual harassment in which victims recount their stories of being assaulted and blackmailed by ABZ.

\begin{tabular}{|c|c|c|}
\hline Strategy & Objectives & Devices \\
\hline $\begin{array}{l}\text { Referential / } \\
\text { Nomination }\end{array}$ & $\begin{array}{l}\text { Discursive construction } \\
\text { of social actors, } \\
\text { objects/phenomena/ and } \\
\text { events, and } \\
\text { processes/actions }\end{array}$ & $\begin{array}{l}\text { - } \text { membership } \\
\text { categorization devices, } \\
\text { deictics, anthroponyms, } \\
\text { etc. } \\
\text { - tropes such as metaphors } \\
\text { - verbs and nouns used to } \\
\text { denote processes and } \\
\text { actions }\end{array}$ \\
\hline Predication & $\begin{array}{l}\text { Discursive qualification } \\
\text { of social actors, objects, } \\
\text { phenomena/ } \\
\text { events/processes, and } \\
\text { actions (more or less } \\
\text { positively or negatively) }\end{array}$ & $\begin{array}{l}\text { - evaluative attributions of } \\
\text { negative or positive traits } \\
\text { - explicit predicates or } \\
\text { predicative nouns/ } \\
\text { adjectives/pronouns } \\
\text { - other }\end{array}$ \\
\hline $\begin{array}{l}\text { Perspectivization, } \\
\text { framing, or } \\
\text { discourse } \\
\text { representation }\end{array}$ & $\begin{array}{l}\text { Positioning speaker's or } \\
\text { writer's point of view } \\
\text { and expressing } \\
\text { involvement or distance }\end{array}$ & $\begin{array}{l}\text { - deictics } \\
\text { - direct, indirect or free } \\
\text { indirect speech } \\
\text { - quotation } \\
\text { discourse } \\
\text { markers/particles } \\
\text { - other }\end{array}$ \\
\hline
\end{tabular}

Table 1

Discursive Strategies - Adapted from Reisigl and Wodak (2009: 104) 
Analysing the discursive strategies in the narratives of victims of an

Egyptian sex predator: a corpus-assisted Discourse Historical approach Dr Wesam M. A. Ibrahim

مجلة وادي النيل للاراسات والبحوث الإنسانية والاجتماعية والتربوية (مجلة علمية محكمة)

\section{Corpus Methods}

In this paper, I use a corpus-assisted Discourse Historical approach. Corpus-linguistic tools are used to deal with large amounts of data (corpora) and to facilitate detecting linguistic patterns. Corpus Linguistics (CL) provides a methodology for systematically investigating corpora using computer software tools (McEnery and Wilson, 2001: 2). This study uses the CL procedures of keywords and concordances.

Scott's (1999) definition of keywords allows for any word to be potentially key if it occurs frequently enough and becomes statistically significant when compared to a reference corpus. Scott classifies three types of keywords: (1) proper nouns, (2) content words which are indicators of the 'aboutness' of a particular text, and (3) function words which may be indicators of style, rather than aboutness. An examination of the keywords in a particular corpus should reveal its most significant lexical features in terms of aboutness and style. Keywords are usually ranked in order of keyness, starting with the most statistically significant or 'strongest' keywords on the top of the keyword list and going to the least statistically significant keywords at the bottom of the list. Since keywords are indicators of a text's topic, or its 'aboutness', what a text is about, they are likely to provide an idea about the topic and plot elements (participants, processes, setting) of the selected narratives. I have used WordSmith5 to extract the keywords of the corpus of all the narratives compiled, using the $B N C$ Sampler-Written as a reference corpus, and setting the 'cutoff' point for determining whether a word was a key-word at $\mathrm{p}=0.000001$, a threshold which is frequently used in corpus-based research (McEnery, 2006: 233). A total of 194 keywords have been extracted, examined and grouped into ten categories according to related or shared semantic space. These categories include pronouns, sex/rape, references to $A B Z$, references to victims, threat and blackmail, communication and social media, body parts and clothes, places, processes for both $A B Z$ and victims and other. 
(ISSN : 2536 - 9555)

WordSmith5 also affords the extraction of concordance lines, thus producing 'all of the examples of a search term in the context that it appears in' (Baker and McEnery, 2005: 202). A concordance, which is also referred to as 'key word in context' (KWIC), yields a particular node word within its immediate co-text, which is usually a specified number of words to the left and right of the node word (Baker, 2006: 71).

Concordance lines constitute the starting point for qualitative analysis. In this paper, concordances of the keywords in the various categories mentioned above are used to qualitatively explore the discursive strategies employed in the narratives. Through revealing the discursive strategies in the narratives, the analysis seeks to answer the following questions.

1. From what perspective are the narratives told?

2. How are $\mathrm{ABZ}$ and the victims presented in the narratives?

3. What qualities are attributed to social actors?

\section{Data and Methodology}

The Instagram account @policeassault includes 100 narratives in the form of screenshots. There are 149 screenshots in total, divided as shown in Table 2 below.

\begin{tabular}{|c|c|c|c|c|c|c|}
\hline Category & $\begin{array}{c}\text { odd } \\
\text { behavior }\end{array}$ & $\begin{array}{c}\text { real-life } \\
\text { harassment }\end{array}$ & $\begin{array}{c}\text { online } \\
\text { harassment }\end{array}$ & $\begin{array}{c}\text { physical } \\
\text { assault }\end{array}$ & $\begin{array}{c}\text { blackmail } \\
\text { and } \\
\text { threat }\end{array}$ & $\begin{array}{c}\text { Au } \\
\text { Spain }\end{array}$ \\
\hline $\begin{array}{c}\text { No. of } \\
\text { Narratives }\end{array}$ & 24 & 64 & 20 & 13 & 24 & 4 \\
\hline
\end{tabular}

Table 2

Division of narratives' screenshots on @assaultpolice Instagram account 
Analysing the discursive strategies in the narratives of victims of an Egyptian sex predator: a corpus-assisted Discourse Historical approach Dr Wesam M. A. Ibrahim

مجلة وادي النيل للاراسات والبحوث الإنسانية والاجتماعية والتربوية (مجلة علمية محكمة)

I excluded the screenshots of conversations allegedly held between ABZ and the victims and focused only on those which provide a personal account of the events whether by the victim herself (62 narratives) or by a friend or a witness (7 narratives). Hence, the selected data include 69 narratives (consisting of about 12,700 words). 53 of the screenshots were numbered using ANON+number and 16 had been given titles such as Girl A, Girl 7, etc. Some of the narratives are long and were provided in more than one screenshot with the label ANON(n) continued. The 69 narratives were manually transcribed and converted to a text file to be processed by WordSmith5.

The analysis was carried out in three steps. The first step was to extract the keywords. From the keywords, I focused only on the content words (pronouns, nouns, verbs, adjectives, and adverbs). In the second step, concordances of the keywords were examined to identify the discursive strategies employed in the narratives. In the third step, the discursive strategies are discussed and explained in relation to the context of the narratives.

\section{Discussion}

\section{Perspectivation}

All narratives are focalized through the victims' perspective. They are all told in the first-person and they give an account of ABZ's activities and history with the victims. As shown in Table 3, the first-person pronouns 'ME' (Freq. 375 - Keyness 1494.7) and 'I' (Freq. 614 - Keyness 1429.9) come at the top of the keyword list. Other pronouns for the first person also get high keyness, including the possessive ' $\mathrm{MY}$ ' and the Arabic first-person singular pronoun 'ANA' [I]. Singular masculine third-person pronouns also get high keyness, with the subject pronoun 'HE' occupying the third place (Freq. 548 - Keyness 1389.8) in addition to the object pronoun 'HIM', the Arabic equivalent of he 'HWA', and the possessive 'HIS'. Other pronouns include a short version of the 
(ISSN : 2536 - 9555)

second-person pronoun you ' $U$ ' which is quite common in online chatting and messaging, an Arabic equivalent of she 'HEYA', the plural first-person pronoun 'WE' and the third-person plural possessive 'THEIR'.

\begin{tabular}{|l|l|l|l|l|l|l|c|}
\hline $\mathbf{N}$ & $\begin{array}{c}\text { Key } \\
\text { word }\end{array}$ & Freq. & \multicolumn{1}{|c}{$\%$} & RC. Freq. & \multicolumn{1}{c|}{ RC. $\%$} & \multicolumn{1}{c|}{ Keyness } & P \\
\hline 1 & ME & 375 & 2.836182117 & 1414 & 0.135349214 & 1494.723999 & $2.56676 \mathrm{E}-19$ \\
\hline 2 & I & 614 & 4.643775463 & 6217 & 0.595096231 & 1429.9198 & $2.94109 \mathrm{E}-19$ \\
\hline 3 & HE & 548 & 4.144607544 & 4890 & 0.468074709 & 1389.80896 & $3.20992 \mathrm{E}-19$ \\
\hline 5 & HIM & 230 & 1.73952508 & 1184 & 0.113333426 & 793.2803955 & $1.82761 \mathrm{E}-18$ \\
\hline 6 & MY & 218 & 1.648767233 & 1951 & 0.186751291 & $\mathbf{5 4 7 . 4 7 9 4 3 1 2}$ & $5.90909 \mathrm{E}-18$ \\
\hline 31 & ANA & 10 & 0.075631522 & 0 & & 87.65116119 & $5.18027 \mathrm{E}-15$ \\
\hline 44 & HWA & 9 & 0.06806837 & 0 & & 78.88536835 & $8.84658 \mathrm{E}-15$ \\
\hline 46 & U & 23 & 0.173952505 & 132 & 0.012635146 & 74.76541138 & $1.1809 \mathrm{E}-14$ \\
\hline 51 & HIS & 118 & 0.892452002 & 4000 & 0.382883221 & 64.18933105 & $2.90757 \mathrm{E}-14$ \\
\hline 121 & HEYA & 4 & 0.030252609 & 0 & & 35.05867004 & $6.7423 \mathrm{E}-10$ \\
\hline 137 & WE & 77 & 0.582362711 & 2985 & 0.285726607 & 30.82310867 & $2.53405 \mathrm{E}-08$ \\
\hline 185 & THEIR & 8 & 0.060505219 & 2713 & 0.259690523 & -29.16301727 & $6.36125 \mathrm{E}-08$ \\
\hline
\end{tabular}

Table 3 Pronouns in the keyword list

The first-person narrators tend to use unmodalized propositions which 'always express higher reliability than propositions involving evaluations of reliability' (Halliday 1994, 89). This tendency is reflected by the relational processes in the keywords list which include forms of the verb be (IS, ARE, WAS) and the equivalent Arabic verbs for was (KAN, KANET, KONT) (see Table 4). This is likely to gain the readers' trust in these narrators' stories since they are given as facts.

\begin{tabular}{|c|c|c|c|c|c|c|c|}
\hline $\mathbf{N}$ & Key word & Freq. & $\%$ & RC. Freq. & RC. \% & Keyness & $\mathbf{P}$ \\
\hline 33 & $\begin{array}{l}\text { KAN } \\
{\left[3^{\text {rd }} \text { m-was }\right]}\end{array}$ & 10 & 0.075631522 & $\mathbf{0}$ & & 87.65116119 & $5.18027 \mathrm{E}-15$ \\
\hline 35 & WAS & 210 & 1.588261962 & 8167 & 0.781751812 & 83.93618774 & $6.42457 \mathrm{E}-15$ \\
\hline 77 & $\mathbf{A M}$ & 25 & 0.189078808 & 313 & 0.02996061 & 48.70334244 & $2.51676 \mathrm{E}-13$ \\
\hline 90 & $\begin{array}{l}\text { KANET [ }{ }^{\text {rd }} \\
\text { f-was] }\end{array}$ & 5 & 0.037815761 & 0 & & 43.8237114 & $8.43846 \mathrm{E}-13$ \\
\hline 166 & $\begin{array}{l}\text { KONT } \\
{\left[1^{\text {st }}-\text { was }\right]}\end{array}$ & 3 & 0.022689456 & 0 & & 26.29377937 & $2.90307 \mathrm{E}-07$ \\
\hline 189 & ARE & 22 & 0.166389346 & 5346 & 0.511723399 & -41.65830612 & $1.78111 \mathrm{E}-12$ \\
\hline 190 & IS & 62 & 0.468915433 & 10231 & 0.979319513 & -43.5556221 & $9.16881 E-13$ \\
\hline
\end{tabular}

Table 4 Relational processes in the keyword list 


\section{Analysing the discursive strategies in the narratives of victims of an Egyptian sex predator: a corpus-assisted Discourse Historical approach Dr Wesam M. A. Ibrahim}

مجلة وادي النيل للاراسات والبحوث الإنسانية والاجتماعية والتربوية (مجلة علمية محكمة)

The depiction of the victims' perceptions and emotions is likely to encourage readers to identify with the victims and, hence, to sympathize with rather than condemn them since they will be more understanding of their suffering. Through first-person narration, readers are given direct access to the victims' inner world. This creates a kind of intimacy and closeness between victims and readers, which is further enhanced through the use of mental processes. The use of mental processes (see Table 5 below), with the victims functioning as actor, is quite important in order to help recipients get an insight into the inner world of the victims and relate to their suffering. The use of mental processes in narratives of sexual abuse is dubbed by Ellen Klosterman (1997) as 'pro-survivor writing', i.e. narratives which 'do not objectify the victim' (1997: 140). Klosterman (1997: 140) adds that if mental processes are omitted from writing, 'it is easier to blame the victim for individual pathology because the context for her decisions, perceptions, and behaviours - crucial for the audience's understanding - are omitted'.

\begin{tabular}{|c|l|l|l|c|c|c|c|}
\hline N & Key word & Freq & $\%$ & $\begin{array}{c}\text { RC. } \\
\text { Freq }\end{array}$ & RC. $\%$ & Keyness & P \\
\hline 65 & KNOW & 38 & 0.287399799 & 627 & $\mathbf{0 . 0 6 0 0 1 6 9 4 1}$ & $\mathbf{5 7 . 5 7 1 6 5 5 2 7}$ & $\mathbf{6 . 1 0 8 2 9 E - 1 4}$ \\
\hline 175 & THOUGHT & 23 & $\mathbf{0 . 1 7 3 9 5 2 5 0 5}$ & $\mathbf{4 9 0}$ & $\mathbf{0 . 0 4 6 9 0 3 1 9 3}$ & $\mathbf{2 6 . 1 5 3 8 2 9 5 7}$ & $\mathbf{3 . 1 2 3 4 7 E - 0 7}$ \\
\hline
\end{tabular}

Table 5 Mental processes in the keyword list

The mental verb know is used 34 times with the pronoun $I$ as actor, of which 32 concordance lines have the pronoun $I$ referring to one of the victims and 2 have the pronoun $I$ referring to ABZ in reported speech. Among these lines, there are 20 affirmative uses of the verb and 14 negative uses with I didn't and I don't before the verb. As shown in the concordance lines in Figure 1 below, there are references by victims to not knowing about the history or misconduct of ABZ (line 1, 7, 9, 21, $38)$, knowing him $(1.5,29,31)$, wanting to know why ABZ specifically chose them $(1.12,14)$, not knowing what to do in response to what was happening to them $(1.6,25,26,29), \mathrm{ABZ}$ executing his threat and calling the victims' contacts $(1.2,3)$, and their determination to strengthen the case against $\mathrm{ABZ}(1.16,17,19)$. 
(ISSN : 2536 - 9555)

\begin{tabular}{|c|c|}
\hline$N$ & Soncord \\
\hline 1 & \multirow{25}{*}{$\begin{array}{l}\text { the head of the school. I don't exactly know what happened but our school } \\
\text { me from other areas and called people I know. He tried calling me a million time } \\
\text { me. He has contacted so many people I know and then told me 'I'm doing this } \\
\text { or have any questions, please let me know. (I would also appreciate it if my } \\
\text { of false shit. } 47 \text { ANON } 64 \text { I personally know him, he's my neighbor w he tried } \\
\text {. I was } 15 \text { at the time and didn't know what to do so I asked my parents } \\
\text { me quite uncomfortable Knowing I don't know this guy and he just asked to live } \\
\text { with it, I don't know the full story but I know his brother isn't a saint and may } \\
\text { and blackmailed her with it, I don't know the full story but I know his } \\
\text { pedophile, a rapist, and I cant stand to know he's still getting away with all of it. } \\
\text { back with him I said idk I just wanted to know what the fuck was that and why. } \\
\text { was wrong with so I called him to know why me, he was very cold, then a } \\
\text { live and somehow make me pay for it (I know it sounds dumb but he's a } \\
\text { a few weeks ago cause I wanted to know why me, and he was cold then } \\
\text { around me at all times otherwise I don't know what could have happened. } 59 \\
\text { them up as well. } 57 \text { ANON } 25 \text { Hi I don't know if it'll help, bas Ahmed zaki da } \\
\text { of it. I thought l'd come forward with all I know to strengthen the case. I think I } \\
\text { el ba3diih because he wanted to get to know me and for us to go out and stuff } \\
\text { I really think we should do smth abt it. I know it's nothing serious compared to } \\
\text { on whispering into my ears stuff like 'I know you like this' 'just give up the } \\
\text { fe seten dayha[03] } 7 \text { ANON } 54 \text { I didn't know the guy at the time but he told me } \\
\text { sexually assaulting a girl (whom I didn't know). They were in his car and he was } \\
\text { driving me home } 12 \text { ANON } 13 \text { I know someone who got assaulted by } \\
\text { 10:30, I want an answer. Peace?" 'You know what, let me send a broadcast to } \\
\text { touch me. I left, yet I didn't break up. I know that I was wrong bas once again, I }\end{array}$} \\
\hline 2 & \\
\hline 3 & \\
\hline 4 & \\
\hline 5 & \\
\hline 6 & \\
\hline 7 & \\
\hline 8 & \\
\hline 9 & \\
\hline 10 & \\
\hline 11 & \\
\hline 12 & \\
\hline 13 & \\
\hline 14 & \\
\hline 15 & \\
\hline 16 & \\
\hline 17 & \\
\hline 18 & \\
\hline 19 & \\
\hline 20 & \\
\hline 21 & \\
\hline & \\
\hline 23 & \\
\hline & \\
\hline 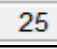 & \\
\hline & \multirow{13}{*}{$\begin{array}{l}\text { was honestly scared for my life. I didn't know what to do. I let him kiss me and } \\
\text { (right away). Like yo, take this. I know l'm such a bitch. But you're a } \\
\text { in his bedroom. I was terrified. I didn't know what to do he broke up with me } \\
\text { several times in the past few years. I know which school he went to and the } \\
\text { He texted me too in May. I don't even know how he found my Instagram } \\
\text { others then blocked him. } 26 \text { ANON } 40 \text { I know this guy too! He added me on } \\
\text { him to dahab 3ala asas 'I love to get to know people when we're travelling' and } \\
\text { yess he slides in so many girls dm's I know in such a slimy creepy way. } 35 \\
\text { hakhedk hacienda w she doesn't even know him w she told him she had a } \\
\text { that has followed me. I even didn't know how he found me on Instagram } \\
18 \text { ANON } 62 \text { Well even don't know what to say about this animal. } \\
\text { of certain places of his body (which you know what I am talking about[025]) And } \\
\text { is so lucky' 'I miss you' I DON'T EVEN KNOW HIM! I told my bf the story and }\end{array}$} \\
\hline 27 & \\
\hline 28 & \\
\hline & \\
\hline 30 & \\
\hline 31 & \\
\hline 32 & \\
\hline & \\
\hline & \\
\hline & \\
\hline 36 & \\
\hline & \\
\hline & \\
\hline
\end{tabular}

Figure 1 Concordance lines for know 
Analysing the discursive strategies in the narratives of victims of an Egyptian sex predator: a corpus-assisted Discourse Historical approach Dr Wesam M. A. Ibrahim

مجلة وادي النيل للاراسات والبحوث الإنسانية والاجتماعية والتربوية (مجلة علمية محكمة)

The mental verb thought is used 21 times with the pronoun $I$ as an actor. This give readers an insight into the victims' thoughts and emotions about ABZ. As seen in Figure 2 below, victims thought ABZ was respectful (1.7), well educated (1.9), a normal classmate (1.12), gentle and decent (1.16), nice and good looking (1.17), very sweet (1.18), and a nice person (1.20). Readers also get to know about the victims' emotions: there are references to a victim's liking of ABZ's attention in her: I thought I was special (1.15); a victim's feeling of love: I thought I was in love with him (1.22), of regret: I thought it was all my fault (1.8), and of shock: I would never thought for second he would do that (1.11)], perceptions [I thought I recognized him (1.21), I thought I could trust this person (1.23)] and determination to share their stories and expose ABZ [I thought I'd come forward with all I know (1.6), many people need proof so I thought I'd share (1.10)].

of school suspension and that was it. I thought .. we all thought it was just a and that was it. I thought ... we all thought it was just a high school phase, believe this is still happening I honestly thought he was just a fuckboy playing he came for me (13 at the time) w I thought kan beyetkalem 3ady la2eto and we had a lot of mutual friends so I thought it was okay. He started with his he's still getting away with all of it. I thought l"d come forward with all I know works in the Intelligence Agency so I thought he would be respectful and A week ago I was at my lowest and I thought it was all my fault and thought for second he would do that as I thought he was well educated, I think and many people need "proof' so I thought l'd share because I really think , I'm 24 and he was 20 . I would never thought for second he would do that as I He asked me "how was the exam?" so I thought he is a normal classmate

Then he took me to his compound. I thought maybe we will just hang there I loved the idea of him or at least how I thought he was. 4 Victim I'm going to and he was sharing things with me I thought I was special so I did the same we have in the compound And I went I thought he is gentle and decent When a nice bike and asked if he can use it I thought he was nice, good looking and 19 at the time. We were talking and I thought he was very sweet, yet I felt and help me (they didn't because they thought I liked him and as he said we him to my friends just because I thought he was a nice person at the this asshole's face all over my feed, I thought I recognized him, and then it hit weirder and weirder by time bas I thought that I was in love with him at at the moment, I sent him nudes since I thought I could trust this person and he

Figure 2 Concordance lines for thought 
مجلة وادي النيل للاراسات والبحوث الإنسانية والاجتماعية والتربوية (مجلة علمية محكمة)

(ISSN : 2536 - 9555)

\section{Nomination and Predication}

How ABZ is constructed largely depends on how he is named and described by the victims. Hence, the analysis provides a list of the naming choices and modifiers with which ABZ was labelled by his victims. '[T]here are many different ways of saying essentially the same thing' and the element of choice produces ideological meaning (Jeffries and McIntyre, 2010: 25).

There is a similarity between all the narratives: almost all victims state that their impression of $A B Z$ when they first met him was that he was a nice and decent person. Then, when they got to know him, they realized that first impressions are not always right. They all suffer various kinds of misconduct by ABZ ranging from verbal violence to blackmail to sexual harassment and even rape.

\begin{tabular}{|c|c|c|c|c|c|c|c|}
\hline $\mathbf{N}$ & Key word & Freq. & $\%$ & $\begin{array}{l}\text { RC. } \\
\text { Freq. }\end{array}$ & $\begin{array}{c}\text { RC. } \\
\% \\
\end{array}$ & Keyness & $\mathbf{P}$ \\
\hline 16 & GUY & 23 & 0.173952505 & 13 & & 154.8545074 & $4.53212 \mathrm{E}-16$ \\
\hline 18 & AHMED & 20 & 0.151263043 & 6 & & 147.3773499 & $5.48923 E-16$ \\
\hline 23 & ZAKI & 13 & 0.098320983 & $\mathbf{0}$ & & 113.9494247 & $1.56547 \mathrm{E}-15$ \\
\hline 94 & RAPIST & 5 & 0.037815761 & $\mathbf{0}$ & & 43.8237114 & $8.43846 \mathrm{E}-13$ \\
\hline 95 & CREEPY & 5 & 0.037815761 & $\mathbf{0}$ & & 43.8237114 & $8.43846 \mathrm{E}-13$ \\
\hline 108 & ASSHOLE & 5 & 0.037815761 & 1 & & 38.44212341 & $9.12679 \mathrm{E}-12$ \\
\hline 134 & DISGUSTING & 5 & 0.037815761 & 4 & & 31.55898094 & $1.64226 \mathrm{E}-08$ \\
\hline 135 & WEIRD & 5 & 0.037815761 & 4 & & 31.55898094 & $1.64226 \mathrm{E}-08$ \\
\hline 167 & KISSER & 3 & 0.022689456 & $\mathbf{0}$ & & 26.29377937 & 2.90307E-07 \\
\hline \multirow[t]{5}{*}{168} & MOTHERFUCKER & 3 & 0.022689456 & $\mathbf{0}$ & & 26.29377937 & 2.90307E-07 \\
\hline & ANIMAL & 4 & 0.030252609 & & & & \\
\hline & NICE & 5 & 0.037815761 & & & & \\
\hline & DECENT & 3 & 0.030252609 & & & & \\
\hline & PSYCHOPATH & 2 & 0.021564161 & & & & \\
\hline
\end{tabular}

Table 6 Keywords used for Naming and Describing ABZ

After being subject to ABZ's abuse, victims construct him as a rapist, as in Figure 6. He is also referred to as a pedophile (1.1) since many of his victims are minors. He is also labelled as an asshole (Fig. 7), an animal (Fig. 8), psychopath (Fig. 9) and a motherfucker (Fig. 10). 
Analysing the discursive strategies in the narratives of victims of an Egyptian sex predator: a corpus-assisted Discourse Historical approach Dr Wesam M. A. Ibrahim

\begin{tabular}{|c|c|}
\hline \multicolumn{2}{|r|}{ مجلة وادي التيل للاراسات والبحوث الإنسانية والاجتماعية والتربوية (مجلة علمية محكمة) } \\
\hline $\mathrm{N}$ & Concordance \\
\hline 1 & all, it became clear. He's a pedophile, a rapist, and I cant stand to know he's \\
\hline 2 & \multirow{4}{*}{$\begin{array}{l}\text { that. I never ever felt that he would be a rapist. Anyways we met only once and } \\
\text { school in Qatar. He was labeled as a rapist since there were rumors going } \\
\text { my personal safety [035]to discuss the rapist Ahmed zaki. While I have } \\
\text { by this. However, in the case of this rapist, allowing him access to the AUC }\end{array}$} \\
\hline 3 & \\
\hline 4 & \\
\hline 5 & \\
\hline
\end{tabular}

Figure 6 Concordance lines for rapist

\begin{tabular}{|c|c|}
\hline N & Concordance \\
\hline 1 & and I .. I am so glad you exposed this asshole ANON 12[033] Yes yess he \\
\hline 2 & with girls. 64 ANON 30 This ahmed zaki asshole at first added me on fb and \\
\hline 3 & who had the worst experience with this asshole. I'm a EU student and \\
\hline 4 & of seeing his face ever since. This asshole deserves to die. 2 Victim Hey \\
\hline 5 & I look at myself in the mirror. ${ }^{\circ}$ I hope the asshole get what he deserves. I would \\
\hline
\end{tabular}

Figure 7 Concordance lines for asshole

\begin{tabular}{|c|c|}
\hline \hline $\mathrm{N}$ & Concordance \\
\hline 1 & even don't know what to say about this animal. But first I wanted to say that I'm \\
\hline 2 & unfortunately I had one class with this animal. One day we had an exam \\
\hline 3 & explain my horrible experience with this animal This is not my real account I \\
\cline { 1 - 1 } 4 & people are saying this, this guy is an animal!!! I cant find the account tho, but \\
\hline
\end{tabular}

Figure 8 Concordance lines for animal

\begin{tabular}{|c|c|}
\hline$N$ & Concordance \\
2 & for it (l know it sounds dumb but he's a psychopath and made it real serious) \\
\hline 2 & silent either Please be careful he's a psychopath and keep spreading \\
\hline
\end{tabular}

Figure 9 Concordance lines for psychopath

\begin{tabular}{|c|c|}
\hline \hline$N$ & Concordance \\
\hline 1 & those other girls feel 37 ANON 77 This motherfucker totally tried to get me to \\
\hline 2 & I told my bf the story and he texted this motherfucker to tell him to back off and \\
case I will 20 Story 2 months ago, this motherfucker used to be in my class, \\
\hline
\end{tabular}

Figure 10 Concordance lines for motherfucker 
مجلة وادي النيل للاراسات والبحوث الإنسانية والاجتماعية والتربوية (مجلة علمية محكمة)

(ISSN : 2536 - 9555)

He is also constructed using a number of negative modifiers including creepy (Fig. 11), disgusting (Fig. 12), and weird (Fig. 13). Note that the modifier creepy is used in negative constructions $(1.2,4)$ to describe ABZ's behaviour at the beginning of the relationship.

\begin{tabular}{|c|c|}
\hline $\mathrm{N}$ & Concore \\
\hline 1 & that I am quite fortunate to realize how creepy he is from the beginning and \\
\hline 2 & \multirow{4}{*}{$\begin{array}{l}\text { friends between us. At first he wasn't so creepy but he was very flirtatious calling } \\
\text { many girls dm's I know in such a slimy creepy way. } 35 \text { Story Actually a few } \\
\text { for days he wasn't flirty or sexual or creepy for few days until he kept asking } \\
\text { easy way to get into my pants". Very creepy". } 29 \text { Story Hii hope all is good, }\end{array}$} \\
\hline 3 & \\
\hline 4 & \\
\hline 5 & \\
\hline
\end{tabular}

Figure 11 Concordance lines for creepy

Disgusting is used to describe ABZ (1.3), his actions $(1.4,5)$, and also the rumours he used to spread if a victim did not do what he wanted (1.1).

\begin{tabular}{|c|c||}
\hline $\mathrm{N}$ & Concordance \\
\hline 1 & go out with him then he would spread disgusting rumors about me. I kept \\
\hline 2 & $\begin{array}{c}\text { up trying to flirt with, one of the most disgusting being one of my friends that } \\
\text { guy when I was a freshman and he was DISGUSTING! I elbowed him in the }\end{array}$ \\
\cline { 1 - 1 } \begin{tabular}{|c|} 
was I had to interfere and obstruct such disgusting action. I broke his car \\
I ranted at him for a while about how disgusting that was and how I hoped he
\end{tabular} \\
\hline 5
\end{tabular}

Figure 12 Concordance lines for disgusting

Weird is used to modify ABZ's conversations (1.1, 5), ways of staring at victims (1.2), of being manipulative (1.4), and the photos he used to send to his victims (1.3). 
Analysing the discursive strategies in the narratives of victims of an Egyptian sex predator: a corpus-assisted Discourse Historical approach Dr Wesam M. A. Ibrahim

مجلة وادي النيل للاراسات والبحوث الإنسانية والاجتماعية والتربوية (مجلة علمية محكمة)

\begin{tabular}{|c|c|}
\hline $\mathrm{N}$ & Concordance \\
\hline 1 & more and more then he kept saying weird stuff and that he likes me and he \\
\hline 2 & and would stare me down really weird. I was deadass so scared and \\
\hline 3 & truecaller after that, he kept sending me weird photos of certain places of his \\
\hline 4 & $\begin{array}{c}\text { we both started talking. He had his own weird ways of being manipulative. For } \\
\text { in my grade and texting them starting weird conversations before he even }\end{array}$ \\
\hline
\end{tabular}

Figure 13 Concordance lines for weird

It should be noted that labelling $\mathrm{ABZ}$ as a rapist, an asshole, an animal, and a psychopath as well as describing him and his behaviour as creepy, disgusting and weird can be ideological because these labels and modifiers are value-loaded. In other words, these labels and modifiers have negative connotations, i.e., a negative meaning attached to a word by virtue of its usage (Jeffries, 2006: 229) and construct a kind of person who is bad, abnormal, immoral and law-breaking. Hence, they are likely to motivate readers to go through a judgmental process and, eventually, take the side of the victims.

The construction of ABZ implicitly contributes to the construction of the victims because offenders and victims are perceived as binary, canonical opposites (Jancarikova, 2013; Tabbert, 2012). As shown in Table 7, the keywords used to label the victims include girls, slut, girl, whore, and girlfriend. The keywords also include modifiers describing the victims' feelings about their trauma, namely, scared, uncomfortable and terrified. 
مجلة وادي النيل للاراسات والبحوث الإنسانية والاجتماعية والتربوية (مجلة علمية محكمة)

(ISSN : 2536 - 9555)

\begin{tabular}{|c|l|l|l|l|l|l|c|}
\hline N & \multicolumn{1}{|c|}{ Key word } & Freq. & \multicolumn{1}{c|}{$\%$} & $\begin{array}{c}\text { RC. } \\
\text { Freq. }\end{array}$ & RC. $\%$ & Keyness & P \\
\hline 19 & GIRLS & 31 & 0.234457716 & 81 & & 141.6642609 & $6.41025 \mathrm{E}-16$ \\
\hline 26 & SLUT & 13 & 0.098320983 & 1 & & 106.7696304 & $2.07606 \mathrm{E}-15$ \\
\hline 28 & SCARED & 11 & 0.083194673 & 1 & & $\mathbf{8 9 . 5 5 8 1 6 6 5}$ & $4.66494 \mathrm{E}-15$ \\
\hline 55 & GIRL & 23 & 0.173952505 & 183 & $\mathbf{0 . 0 1 7 5 1 6 9 0 7}$ & $\mathbf{6 2 . 0 3 5 2 4 7 8}$ & $3.63059 \mathrm{E}-14$ \\
\hline 82 & WHORE & 7 & 0.052942067 & 4 & & 47.03420639 & $3.61274 \mathrm{E}-13$ \\
\hline 84 & GIRLFRIEND & 6 & 0.045378912 & 1 & & 46.87241745 & $3.75068 \mathrm{E}-13$ \\
\hline 143 & UNCOMFORTABLE & 6 & 0.045378912 & 12 & & 29.97610092 & $4.08157 \mathrm{E}-08$ \\
\hline 150 & TERRIFIED & 5 & 0.037815761 & 7 & & 27.69908333 & $\mathbf{1 . 3 8 8 0 5 E - 0 7}$ \\
\hline
\end{tabular}

Table 7 Keywords used for Naming and Describing the victims

ABZ constructs his victims using the labels slut (Fig. 14), whore (Fig.15) and girlfriend (Fig. 16). As shown in the concordances, he uses the degrading labels slut and whore either to insult the victims or to threaten them with destroying their reputations among their contacts.

\begin{tabular}{|c|c|}
\hline N & Concordance \\
\hline 1 & would call me and tell me that I was a slut and that I have to sleep with him \\
\hline 2 & will be ruined and l'll be known as a slut. He even said he will come to my \\
\hline 3 & mad and call us degrading names like slut and whore. He did this to a lot of \\
\hline 4 & coming to his house. He called me a slut and kept trying to pressure me into \\
\hline 5 & with guys and that I was calling her a slut which is obviously not true. $\mathrm{He}$ \\
\hline 6 & him he'd tell everyone that she was a slut who tried to sleep with him. She \\
\hline 7 & I'll hurt you and tell your friends what a slut $u$ are' he kept making his way down \\
\hline 8 & not different than the other girls. Whore. Slut'. I left and I called my mom, I told \\
\hline 9 & all he had to say 'go to your uncle now slut'. You're not different than the other \\
\hline 10 & he left me and told me go off to ur car slut or u need my dick to give a ride \\
\hline 11 & here' 'you have nice boobs' 'you're my slut' I knew where this was going and I \\
\hline 12 & to school with, telling them that I am a slut and that I should change. He kept \\
\hline 13 & me the next day \& he kept calling me a slut \& a whore. He then told me it's \\
\hline
\end{tabular}

Figure 14 Concordance lines for slut 
Analysing the discursive strategies in the narratives of victims of an Egyptian sex predator: a corpus-assisted Discourse Historical approach Dr Wesam M. A. Ibrahim

مجلة وادي النيل للاراسات والبحوث الإنسانية والاجتماعية والتربوية (مجلة علمية محكمة)

\begin{tabular}{|c|c||}
\hline $\mathrm{N}$ & Concordance \\
\hline 1 & to school with and tell them that l'm a whore and send them my pictures. He \\
\hline 2 & me a tease, playing hard to get and a whore. 27 Anon 22 I met him once at a \\
\cline { 1 - 1 } 3 & $\begin{array}{c}\text { call us degrading names like slut and whore. He did this to a lot of girls at my } \\
\text { next day he kept telling me that I'm a whore and then he told me that it's }\end{array}$ \\
\cline { 1 - 1 } 5 & $\begin{array}{c}\text { You're not different than the other girls. Whore. Slut'. I left and I called my mom, } \\
\text { day \& he kept calling me a slut \& a whore. He then told me it's either I }\end{array}$ \\
\cline { 1 - 1 } 7 & . I know l'm such a bitch. But you're a whore. And you're gonna get down on \\
\hline
\end{tabular}

Figure 15 Concordance lines for whore

As for the label girlfriend, ABZ either asks a victim to be his girlfriend $(1.1,4)$ or to tell people that she is his girlfriend $(1.5,6)$. Line 2 presents one of the ways ABZ entices his victims at the beginning of a relationship by telling them stories about him being victimized by an ex-girlfriend. Line 3 is a part of the narrative of the only male victim in the corpus. He is a Canadian young man who was a fellow student of ABZ's at the AUC and when he left for his country ABZ accused him of being a sexual harasser and tried to ruin his reputation.

\begin{tabular}{|c|c|}
\hline $\mathrm{N}$ & Concordance \\
\hline 1 & always on my mind and will you be my girlfriend. Many times he tried to \\
\hline 2 & \multirow{5}{*}{$\begin{array}{l}\text { me, then a made-up sob story about his girlfriend. When I told him no for the } \\
\text { that I'm a predator and I assaulted his girlfriend. Shocked about this, I quickly } \\
\text { we start dating \& I accept being his girlffiend or he's going to kill himsell. } \\
\text { me en he told his sister that I'm his girlfriend w en he wants to introduce me } \\
\text { to introduce me to his friends as his girlfriend a radeit 3aleh be en ehna }\end{array}$} \\
\hline 3 & \\
\hline 4 & \\
\hline 5 & \\
\hline 6 & \\
\hline
\end{tabular}

Figure 16 Concordance lines for girlfriend

Conversely, the modifiers uncomfortable (Fig. 17), scared (Fig. 18) and terrified (Fig. 19) are used by the victims. These modifiers provide readers with access to the inner feelings of the victims. In line 1, uncomfortable is used to justify a victim's deletion of the evidence for her story, her chat with ABZ. Lines 2, 3,5 and 6 describe victims being uncomfortable about ABZ's 
مجلة وادي النيل للاراسات والبحوث الإنسانية والاجتماعية والتربوية (مجلة علمية محكمة)

(ISSN : 2536 - 9555)

sexual advances. Line 4 is the only instance of the word used by ABZ while threatening a victim to expose their sexual encounter to her father.

\begin{tabular}{|c|c|}
\hline $\mathrm{N}$ & Concordance \\
\hline 1 & however I deleted the chat because I felt uncomfortable, however I still have one \\
\hline 2 & that is not normal (touching), I felt uncomfortable and wanted to leave. He \\
\hline 3 & and sexually harassed me and me so uncomfortable for a very long time I \\
\hline 4 & to me about my dad. And that he was uncomfortable doing that And he called \\
\hline 5 & don't I am being honest Yeah it's just uncomfortable Why? Never kissed a \\
\hline 6 & a great kisser" and that made me quite uncomfortable Knowing I don't know \\
\hline
\end{tabular}

Figure 17 Concordance lines for uncomfortable

As shown in Figures 18 and 19, all the uses of scared and terrified have the victims as actors in the agent position. They are used to describe the victims' feelings during the process of being sexually assaulted and after.

\begin{tabular}{|c|c|}
\hline N & Concordance \\
\hline 1 & and she blocked him. Or post it l'm not scared of him anymore A week ago I \\
\hline 2 & \multirow{10}{*}{$\begin{array}{l}\text { was at night and there was no one, I felt scared and he tried to do more things } \\
\text { to blackmail of us. I was genuinely scared of him I was only } 13,14 \text { at the } \\
\text { then realization [030]culture - scared to share or reveal identity [031]ill } \\
\text { all my social media BCs I was scared of him doing anything to my } \\
\text { me down really weird. I was deadass so scared and confused of what he was } \\
\text { blocked him everywhere and have been scared of seeing his face ever since. } \\
\text { in a compound and I was honestly scared for my life. I didn't know what to } \\
\text { My friend knew this guy as well. She's scared to share the story so I asked her } \\
\text { KEEP ME ANONYMOUS!!! I am still scared. } 41 \text { ANON } 74 \text { Bb I had } 2 \\
\text { move me schools because I was so scared. He sent me a photoshpped }\end{array}$} \\
\hline 3 & \\
\hline 4 & \\
\hline 5 & \\
\hline 6 & \\
\hline 7 & \\
\hline 8 & \\
\hline 9 & \\
\hline 10 & \\
\hline 11 & \\
\hline
\end{tabular}

Figure 18 Concordance lines for scared 
Analysing the discursive strategies in the narratives of victims of an Egyptian sex predator: a corpus-assisted Discourse Historical approach Dr Wesam M. A. Ibrahim

مجلة وادي النيل للاراسات والبحوث الإنسانية والاجتماعية والتربوية (مجلة علمية محكمة)

\begin{tabular}{|c|c|}
\hline \hline$N$ & Concordance \\
\hline 1 & down. I cant express how much I was terrified on what he couldve done. At \\
\hline 2 & $\begin{array}{c}\text { arm, I have no words to describe how terrified I was. He then said yala emshy } \\
\text { her something like that[08] I was so terrified that I did meet up with him out } \\
3\end{array}$ \\
\cline { 1 - 1 } 4 & $\begin{array}{c}\text { believes me because no one did. I was terrified I didn't love him I loved the idea } \\
\text { video of us being in his bedroom. I was terrified. I didn't know what to do he }\end{array}$ \\
\hline
\end{tabular}

Figure 19 Concordance lines for terrified

In order to shed light on how the events in the narratives are constructed and convey the experiences of these victims of sexual abuse, all processes in the keywords were extracted and classified using Halliday's transitivity model (Simpson 2004). Transitivity is a system which construes experiences in terms of a set of process types and relates them to the participants and circumstances involved in the production of the clause. It 'shows how speakers encode in language their mental picture of reality and how they account for their experience of the world around them' (Simpson, 1993: 88). Different types of processes used in a text contribute to the construction of a world view and thus ideation (Tabbert, 2016: 87). The processes expressed by the verbal element of the clause have three potential components: the process itself (which is expressed by a verb phrase), participants involved in the process (which are usually realized by noun phrases), and any circumstances involved in the process (which usually contain adverbial and prepositional phrases). The transitivity model 'assigns lexical verbs to a number of different categories, according to the kind of process or state they appear to be describing' (Jeffries, 2010: 40). These categories include material, verbalisation, mental and relational processes. Material processes, processes of doing, are associated with two inherent participant roles which are the Actor, an obligatory role in the process, and a Goal (the affected participant), a role which may or may not be involved in the process depending on whether the verb is transitive or intransitive (Simpson, 2004: 22). Verbalisation processes are 
(ISSN : 2536 - 9555)

processes of saying and are associated with the participant roles of Sayer (the producer of the speech), Receiver (the entity to which the speech is addressed) and Verbiage (that which gets said) (Simpson, 2004: 24). Mental processes are essentially processes of sensing and are associated with two participant roles: Sensor (the conscious being that is doing the sensing) and Phenomenon (the entity which is sensed, felt, thought or seen) (Simpson, 2004: 23). They 'involve cognition (encoded in verbs such as 'thinking' or 'wondering'), reaction (as in 'liking' or 'hating') and perception (as in 'seeing' or 'hearing')' (Simpson, 2004: 23). Relational processes are processes of being. They establish a relationship between entities and can be divided into three main sub-types: intensive processes (which posit a relationship of equivalence, an ' $\mathrm{x}$ is $\mathrm{y}$ ' connection, between two entities), possessive processes (which express a relationship of ownership) or circumstantial processes (which relate to the time or place of the state with the circumstantial element upgraded to fulfil the role of a full participant in the process) (Simpson, 2004: 24).

The mental and relational processes identified in the keywords are discussed in the perspectivation section. Verbalization processes in the keyword list include told, asked, talk and tell (see Table 8).

\begin{tabular}{|c|l|l|l|l|l|l|c|}
\hline $\mathrm{N}$ & $\begin{array}{c}\text { Key } \\
\text { word }\end{array}$ & Freq. & \multicolumn{1}{c|}{$\%$} & RC. Freq. & \multicolumn{1}{|c|}{ RC. $\%$} & \multicolumn{1}{c|}{ Keyness } & P \\
\hline 11 & TOLD & 72 & $\mathbf{0 . 5 4 4 5 4 6 9 6 2}$ & 373 & $\mathbf{0 . 0 3 5 7 0 3 8 6}$ & $\mathbf{2 4 6 . 8 0 6 9 3 0 5}$ & $\mathbf{8 . 3 0 1 0 4 E - 1 7}$ \\
\hline 54 & ASKED & 33 & $\mathbf{0 . 2 4 9 5 8 4 0 1 9}$ & 425 & $\mathbf{0 . 0 4 0 6 8 1 3 4}$ & $\mathbf{6 2 . 8 0 4 6 0 7 3 9}$ & $3.34737 \mathrm{E}-14$ \\
\hline 104 & TALK & 17 & $\mathbf{0 . 1 2 8 5 7 3 5 9 6}$ & 172 & $\mathbf{0 . 0 1 6 4 6 3 9 7 8}$ & $\mathbf{3 9 . 0 2 4 0 8 9 8 1}$ & $\mathbf{6 . 3 0 8 3 8 E - 1 2}$ \\
\hline 146 & TELL & 18 & $\mathbf{0 . 1 3 6 1 3 6 7 4}$ & $\mathbf{2 7 8}$ & $\mathbf{0 . 0 2 6 6 1 0 3 8 4}$ & $\mathbf{2 9 . 0 8 4 9 3 2 3 3}$ & $\mathbf{6 . 6 3 4 9 E - 0 8}$ \\
\hline
\end{tabular}

Table 8 Verbalization processes

Material processes are quite important for the purposes of this paper. They are extracted from the keyword list, as shown in Table 9 below. My analysis of material processes focuses specifically on the activity or passivity of the participants. 
Analysing the discursive strategies in the narratives of victims of an Egyptian sex predator: a corpus-assisted Discourse Historical approach Dr Wesam M. A. Ibrahim

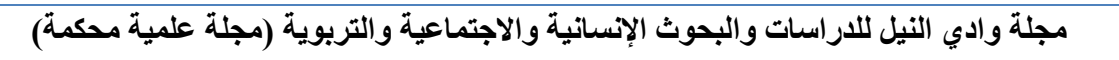

\begin{tabular}{|c|c|c|c|c|c|c|c|}
\hline $\mathbf{N}$ & Key word & Freq. & $\%$ & $\begin{array}{c}\text { RC. } \\
\text { Freq. }\end{array}$ & RC. $\%$ & Keyness & $\mathbf{P}$ \\
\hline 10 & KEPT & 66 & 0.499168038 & 132 & 0.012635146 & 330.0186462 & 3.08413E-17 \\
\hline 14 & TRIED & 39 & 0.294962943 & 138 & 0.013209471 & 158.7081604 & $4.12482 \mathrm{E}-16$ \\
\hline 15 & TEXTED & 18 & 0.13613674 & $\mathbf{0}$ & & 157.7828522 & $4.21802 \mathrm{E}-16$ \\
\hline 17 & BLOCKED & 21 & 0.158826202 & 8 & & 150.1234589 & $5.10893 \mathrm{E}-16$ \\
\hline 24 & STARTED & 33 & 0.249584019 & 174 & 0.016655419 & 112.0469666 & $1.68276 \mathrm{E}-15$ \\
\hline 76 & WENT & 32 & 0.242020875 & 517 & 0.049487654 & 49.50400162 & $2.14664 \mathrm{E}-13$ \\
\hline 80 & KISS & 10 & 0.075631522 & 24 & & 47.06016922 & 3.59123E-13 \\
\hline 83 & SUCK & 7 & 0.052942067 & 4 & & 47.03420639 & $3.61274 \mathrm{E}-13$ \\
\hline 85 & HARASSED & 6 & 0.045378912 & 1 & & 46.87241745 & $3.75068 \mathrm{E}-13$ \\
\hline 99 & GO & 34 & 0.257147193 & 666 & 0.063750051 & 42.7876091 & 1.1789E-12 \\
\hline 109 & THREATENED & 10 & 0.075631522 & 42 & & 37.79344177 & $1.46551 \mathrm{E}-11$ \\
\hline 111 & STOP & 15 & 0.113447286 & 137 & 0.01311375 & 36.98132706 & 3.01899E-11 \\
\hline 128 & BLACKMAIL & 4 & 0.037815761 & 3 & & 33.31413269 & 4.91637E-09 \\
\hline 131 & CONVINCE & 6 & 0.045378912 & 10 & & 31.67030334 & $1.53448 \mathrm{E}-08$ \\
\hline 138 & RUIN & 5 & 0.037815761 & 5 & & 30.08649063 & 3.83953E- 08 \\
\hline 140 & ASSAULTED & 4 & 0.030252609 & 1 & & 30.07979202 & $3.85382 \mathrm{E}-08$ \\
\hline 141 & HARASS & 4 & 0.030252609 & 1 & & 30.07979202 & $3.85382 \mathrm{E}-08$ \\
\hline 152 & SEND & 11 & 0.083194673 & 98 & & 27.57370949 & $1.48296 \mathrm{E}-07$ \\
\hline 160 & FUCKED & 3 & 0.022689456 & 0 & & 26.29377937 & 2.90307E-07 \\
\hline 165 & MESSAGED & 3 & 0.022689456 & 0 & & 26.29377937 & 2.90307E-07 \\
\hline 180 & GRABBED & 5 & 0.037815761 & 11 & & 24.225534444 & $8.53962 \mathrm{E}-07$ \\
\hline 181 & RAPE & 2 & 0.037815761 & 11 & & 24.22553444 & $8.53962 \mathrm{E}-07$ \\
\hline
\end{tabular}

Table 9 Material Processes

The material processes are divided into groups based on their semantic domain. One group relates to sexual activities and includes kiss, suck, harassed, assaulted, harass, fucked, and rape. In almost all the concordances, the material process kiss has the pronoun he referring to $\mathrm{ABZ}$ as the actor and the pronoun me referring to the victims as the goal. Exceptions include reported speech cases in which ABZ asks the victim to kiss him: line 1 (let me kiss you), 1.2 (loosen up kiss me), and 1.10 (I wanna kiss you). Also, in line 7 a victim reports that ABZ asked her to kiss him (he started asking me to kiss him). 
مجلة وادي النيل للاراسات والبحوث الإنسانية والاجتماعية والتربوية (مجلة علمية محكمة)

(ISSN : 2536 - 9555)

\begin{tabular}{|c|c|}
\hline N & Concordance \\
\hline 1 & act and loosen up' 'kiss me' 'let me kiss you' and I kept on saying no but he \\
\hline 2 & give up the tough act and loosen up' 'kiss me' 'let me kiss you' and I kept on \\
\hline 3 & He proceeded to grab my thighs and kiss me, I'm sorry this is very hard to \\
\hline 4 & red flags. When we first met, he tried to kiss me and then he tried to force me to \\
\hline 5 & he is fucking dead' And after he tried to kiss me and touch me in his car, btw I \\
\hline 6 & life. I didn't know what to do. I let him kiss me and continued crying. It didn't \\
\hline 7 & minded... Then he started asking me to kiss him, going back to the same flirting. \\
\hline 8 & stopped at a parking lot \& he tried to kiss me. I kept pushing him away \\
\hline 9 & keter nekalem $w$ keda, he tried to kiss me ghasb 3any w lama kont bab2a \\
\hline 10 & y2olaha ur so hot w muzza w I wanna kiss you and make you go crazy w \\
\hline
\end{tabular}

Figure 20 Concordance lines for kiss

The material process suck has the goal as my $c^{* * k}$ and me in reported speech where $\mathrm{ABZ}$ requests the victims to do this action for him $(1.1,4,5)$. It has the goal as him in the victim's account of how he forced, made or threatened them to do this action $(1.2,3,6$, 7).

\begin{tabular}{|c|c|}
\hline $\mathrm{N}$ & Concordance \\
\hline 1 & to shut up about it. So, are you gonna suck my $c^{\star \star} k$ or should I tell your sister. \\
\hline 2 & \multirow{6}{*}{$\begin{array}{l}\text { kiss me and then he tried to force me to suck him off. Keep in mind, I was } 14 \text { at } \\
\text { himself into me and told me if I didn't suck him off he would tell my dad that I } \\
\text { gonna get down on your knees and suck my c }{ }^{\star \star} k \text { for me to shut up about it. } \\
\text { Then he took off his pants And told me suck me off little bitch He raped me but } \\
\text { to pin me down and to make me suck him off. However, I got away since } \\
\text { resisting him. He then tried to make me suck him off again, yet I managed to }\end{array}$} \\
\hline 3 & \\
\hline 4 & \\
\hline 5 & \\
\hline 6 & \\
\hline 7 & \\
\hline
\end{tabular}

Figure 21 Concordance lines for suck

The process harassed has the pronoun he (referring to ABZ) as the actor in all concordance lines. It has the pronoun me $(1.1,2,3,4)$, my friend (1.5) and one of my best friends (1.6) in the goal slot. The process also has the adverb modifiers sexually $(1.2,4,5)$ and verbally (1.6). 
Analysing the discursive strategies in the narratives of victims of an Egyptian sex predator: a corpus-assisted Discourse Historical approach Dr Wesam M. A. Ibrahim

\begin{tabular}{|c|c|}
\hline \multicolumn{2}{|r|}{ مجلة وادي التيل للار اسات والبحوث الإنسانية والاجتماعية والتربوية (مجلة علمية محكمة) } \\
\hline $\mathrm{N}$ & Concordance \\
\hline 1 & with .... and I in high school. And he harassed me and many other girls. He \\
\hline 2 & that he also black mailed and sexually harassed me and me so uncomfortable \\
\hline 3 & in prison' 68 Story Shady dah mor3b he harassed me, my sister, and my friends. \\
\hline 4 & leave. 16 Story This guy ... he sexually harassed me and forced himself on me!! \\
\hline 5 & OMG same thing happened he sexually harassed my friend and I .. I am so glad \\
\hline 6 & Qatar' that year. He would verbally harassed one of my best friends and \\
\hline
\end{tabular}

Figure 22 Concordance lines for harassed

The process assaulted is used in passive constructions in lines 1 and 3 whereby ABZ is the doer of the action (assaulted by him). In line 2, the actor is occupied by the pronoun $I$ (referring to the Canadian guy accused by ABZ of being a sexual predator) and the goal is occupied by the noun phrase his girlfriend (with his in this construction to be interpreted as ABZ's)

\begin{tabular}{|c|c|}
\hline N & Concordance \\
\hline 1 & zaki. While I have thankfully not been assaulted by him, I have seen him \\
\hline 2 & telling them that I'm a predator and I assaulted his girlfriend. Shocked about \\
\hline 3 & 12 ANON 13 I know someone who got assaulted by him twice and he kept \\
\hline 4 & her for nudes 13 ANON 11 Yo HE ASSAULTED ME WHEN I WAS 15 \\
\hline
\end{tabular}

Figure 23 Concordance lines for assaulted

As mentioned above with harassed, the process harass also has the pronoun he (referring to ABZ) as the actor in all concordance lines. The goal is occupied by the pronoun me $(1.1,2,4)$ and women (1.3). The process is modified by the adverb verbally in line 1 .

\begin{tabular}{|c|c|}
\hline \hline $\mathrm{N}$ & Concordance \\
\hline 1 & but he didn't care. He used to verbally harass me saying how pretty I was and \\
\hline 2 & $\begin{array}{c}\text { anything, oh he also used to call and harass me at horrible times like } 3 \text { am } \\
\text { are unguarded and often empty and harass women. Moreover, l'd like to } \\
\text { him, he's my neighbor w he tried to harass me abl keda aktar men mara w }\end{array}$ \\
\hline 4 &
\end{tabular}

Figure 24 Concordance lines for harass 
مجلة وادي النيل للاراسات والبحوث الإنسانية والاجتماعية والتربوية (مجلة علمية محكمة)

(ISSN : 2536 - 9555)

As shown in Figure 25, fucked is used as a material process in line 2 (he fucked me anal) and as a past-participle adjective in line 1 (how fucked he is) and line 3 (get fucked).

\begin{tabular}{|c|c|}
\hline \hline$N$ & Concordance \\
\hline 1 & wasn't enough for him to realise how fucked he is. Anyways I went back to \\
\hline 2 & me but not the normal thing But he fucked me anal Which's really \\
\hline 3 & kept crying really hard He told me u get fucked or killed It's ur choice lt's up to u \\
\hline
\end{tabular}

Figure 25 Concordance lines for fucked

The process rape is used once with the pronoun he (referring to ABZ) as the actor and the pronoun me (referring to one of the victims) as the goal (1.1). Line 2, on the other hand, has the pronoun they (referring to ABZ's group).

\begin{tabular}{|c|c|}
\hline \hline $\mathrm{N}$ & Concordance \\
\hline 1 & home and I went over there. He tried to rape me and then I quickly left. The \\
\hline 2 & His whole friend group They drug and rape girls He texted my friends older \\
\hline
\end{tabular}

Figure 26 Concordance lines for rape

The process grabbed belongs to the semantic domain of violence but, in the corpus, it is always associated with ABZ's sexual advances. It has the pronoun he (referring to $\mathrm{ABZ}$ ) as the actor in all concordance lines and the pronoun me (1.1, 2, 3), my hair (1.4) and my neck (1.5) as the goal.

\begin{tabular}{|c|c|}
\hline $\mathrm{N}$ & Concordance \\
\hline 1 & my friends and he followed me there, he grabbed me by my waist in front of my \\
\hline 2 & $\begin{array}{c}\text { something was wrong. He came back, grabbed me by the waist AGAIN and } \\
\text { That day he followed us to that spot and grabbed me by my arm, and when I } \\
\text { and managed to get out of his room. He grabbed my hair and threw me on the } \\
45\end{array}$ \\
\cline { 1 - 1 } 5 & kissing me and leaning in closer till he grabbed my neck[010] a told me not to \\
\hline
\end{tabular}

Figure 27 Concordance lines for grabbed 
Analysing the discursive strategies in the narratives of victims of an Egyptian sex predator: a corpus-assisted Discourse Historical approach Dr Wesam M. A. Ibrahim

مجلة وادي النيل للاراسات والبحوث الإنسانية والاجتماعية والتربوية (مجلة علمية محكمة)

In addition to grabbed, the use of the processes assaulted, fucked, grabbed and rape convey to readers a sense of ABZ's violence with the victims.

The context of rape and sexual abuse relate to other keywords referring to body parts and items of clothing, see Table 10.

\begin{tabular}{|c|l|l|l|l|l|l|l|}
\hline $\mathbf{N}$ & $\begin{array}{c}\text { Key } \\
\text { word }\end{array}$ & Freq. & \multicolumn{1}{c|}{$\%$} & $\begin{array}{c}\text { RC. } \\
\text { Freq. }\end{array}$ & $\begin{array}{c}\text { RC. } \\
\%\end{array}$ & Keyness & \multicolumn{1}{c|}{$\mathbf{P}$} \\
\hline 62 & PANTS & 9 & 0.06806837 & 5 & & 60.76187134 & $\begin{array}{l}4.17389 \mathrm{E}- \\
14\end{array}$ \\
\hline 116 & BOOBS & 4 & 0.030252609 & 0 & & 35.05867004 & $6.7423 \mathrm{E}-10$ \\
\hline 139 & THIGHS & 4 & 0.030252609 & 1 & & 30.07979202 & $\begin{array}{l}3.85382 \mathrm{E}- \\
08\end{array}$ \\
\hline & HANDS & 5 & 0.037815761 & & & & \multicolumn{2}{|}{} \\
\hline & DICK & 3 & 0.022689456 & & & & \\
\hline
\end{tabular}

Table 10 Body parts and items of clothing

The clothing item pants is mentioned 9 times in the corpus either as part of the victim's clothing (x 7) or ABZ's (x 2). There is a reference to ABZ pushing down (1.3) or taking off (1.6) his pants. The concordance lines reveal ABZ's sexual advances while trying to get into $(1.1,2)$, making his way down $(1.4,7)$, taking off $(1.8)$ or unbuttoning $(1.5,9)$ the victim's pants.

\begin{tabular}{|c|c|}
\hline $\mathrm{N}$ & Concordance \\
\hline 1 & was probably his way of getting in my pants, but I obviously rejected since I \\
\hline 2 & \multirow{8}{*}{$\begin{array}{l}\text { if there was 'an easy way to get into my pants". Very creepy". } 29 \text { Story Hii hope } \\
\text { grab my hand and push it down his pants whenever we were alone. He'd } \\
\text { and tried to put his hands down my pants and would grab my hand and } \\
\text { thighs, he then started to unbutton my pants and slipping his hand into my } \\
\text { my nipples Then he took off his pants And told me suck me off little } \\
\text {, and he was making his way down my pants. I kept saying no and I tried to get } \\
\text {, while begging him to stop. He took my pants off and he tried to touch me, yet I } \\
\text { me on the floor. He unbuttoned my pants and I was shaking and crying and }\end{array}$} \\
\hline 3 & \\
\hline 4 & \\
\hline 5 & \\
\hline 6 & \\
\hline 7 & \\
\hline 8 & \\
\hline 9 & \\
\hline
\end{tabular}

Figure 28 Concordance lines for pants 
مجلة وادي النيل للاراسات والبحوث الإنسانية والاجتماعية والتربوية (مجلة علمية محكمة)

(ISSN : 2536 - 9555)

In texts about sexual violence, body parts are relevant to the material processes whether they are those of the victim or the abuser. ABZ physically harasses the victims through grabbing (1.3) or groping (1.4) their boobs. He also verbally harasses his victims either by praising her boobs (1.1) or asking what size they are (1.2).

\begin{tabular}{|c|l|}
\hline \hline $\mathrm{N}$ & Concordance \\
\hline 1 & a pretty girl like you here' 'you have nice boobs' 'you're my slut' I knew where this \\
\hline 2 & $\begin{array}{c}\text { saw once, and asked me what size my boobs were ... I ignored it, and asked } \\
\text { nothing changes He started to grab my boobs then I started to scream really } \\
\text { me and then he started to grope my boobs while I kept begging him to stop }\end{array}$ \\
\hline 4 & \begin{aligned} me \\
\hline\end{aligned}
\end{tabular}

Figure 29 Concordance lines for boobs

The references to the victims' thighs describe the process of the sexual abuse with ABZ grabbing (1.1), making his way down (1.2) or moving his hands on $(1.3,4)$ the victim's thighs.

\begin{tabular}{|c|c|}
\hline N & Concordance \\
\hline 1 & didn't stop. He proceeded to grab my thighs and kiss me, I'm sorry this is \\
\hline 2 & u are' he kept making his way down my thighs and that's when I had this feeling \\
3 & $\begin{array}{r}\text { He moved his hands down till my thighs and kept swaying his hands up } \\
\text { swaying his hands up and down on my thighs, he then started to unbutton my }\end{array}$ \\
\hline
\end{tabular}

Figure 30 Concordance lines for thighs

The use of hands also relates to the process of sexual abuse. As in Figure 31, ABZ uses his hand to suppress his victim leaving a scar on her body (1.1), to get down the victim's pants (1.2), to move down her thighs $(1.3,5)$. In these cases, ABZ's hands are typically constructed as the active agent in the abuse process. On the other hand, when the victim's hands are mentioned (1.4), they are being held at her back, suppressed to hold her back showing her disempowerment and physical entrapment. 
Analysing the discursive strategies in the narratives of victims of an Egyptian sex predator: a corpus-assisted Discourse Historical approach Dr Wesam M. A. Ibrahim

\begin{tabular}{|c|c|}
\hline \multicolumn{2}{|r|}{ مجلة وادي النيل للاراسات والبحوث الإنسانية والاجتماعية والتربوية (مجلة علمية محكمة) } \\
\hline $\mathrm{N}$ & Concordance \\
\hline 1 & me so strong I still have a scar from his hands. 17 ANON 2 I no longer have \\
\hline 2 & to sketchy places and tried to put his hands down my pants and would grab \\
\hline 3 & till my thighs and kept swaying his hands up and down on my thighs, he \\
\hline 4 & my t shirt to my mouth and holed my hands to my back Then took off my t \\
\hline 5 & him or he'll hurt me[011]. He moved his hands down till my thighs and kept \\
\hline
\end{tabular}

Figure 31 Concordance lines for hands

Finally, the word dick is used in the corpus 3 times: ABZ tended to send pictures of his aroused penis to his victims (1.1); one of the victims mentioned that $\mathrm{ABZ}$ had an erection while touching her from behind (1.2); and, in a conversation between ABZ and one of his victims after raping her anally he shouted at her to leave and drive home and insulted her saying 'or $u$ need my dick to give a ride home'.

\begin{tabular}{|c|l|}
\hline \hline $\mathrm{N}$ & Concordance \\
\hline 1 & But after a while of talking he sent me a dick pic on snapchat out of the blue and \\
\hline 2 & $\begin{array}{c}\text { waraya yelza2 feya also I almost felt his dick begad, and I immediately ordered } \\
\text { me go off to ur car slut or u need my dick to give a ride home I couldn't even }\end{array}$ \\
\hline 3 &
\end{tabular}

Figure 32 Concordance lines for dick

Another group of processes relates to the semantic domain of threat and blackmail. It includes the processes threatened and blackmail. As shown in Figure 28, the pronoun he, referring to $\mathrm{ABZ}$, is used as the actor in all concordance lines. The goal position is occupied by me (1.3, 6, 7, 10), us (1.1), and her (1.9). Other concordances do not have a participant as the goal but have an infinitive reflecting what $\mathrm{ABZ}$ threatens to do: 'to tell my whole family' (1.2), 'to blackmail' (1.4), 'to physically hurt me' (1.5), and 'to spread more shit' (1.8). 
مجلة وادي النيل للاراسات والبحوث الإنسانية والاجتماعية والتربوية (مجلة علمية محكمة)

(ISSN : 2536 - 9555)

\begin{tabular}{|c|c|}
\hline \hline $\mathrm{N}$ & Concordance \\
\hline 1 & her \& I tried to get revenge from him he threatened us by saying that hes going \\
\hline 2 & $\begin{array}{c}\text { and called me so many names. He threatened to tell my whole family and } \\
\text { me, sent me unsolicited nudes then threatened me to share my 'fake nudes' } \\
\text { me, my sister, and my friends. He threatened to blackmail of us. I was }\end{array}$ \\
\hline 4 & $\begin{array}{c}\text { we dating and I tried to dump him he threatened to physically hurt me if I try } \\
\text { right now. He threatens people. He threatened me to call me parents and }\end{array}$ \\
\hline 6 & \begin{tabular}{c} 
am not a therapist or anything. He then threatened me and told me if I didn't \\
some rumours about us dating and threatened to spread more shit about \\
\hline 7
\end{tabular} \\
\hline 9 & $\begin{array}{c}\text { harassed one of my best friends and threatened her. She was } 13 \text { and he was } \\
\text { young, and when I tried to cut him off he threatened me that he's gonna kill me }\end{array}$ \\
\hline
\end{tabular}

Figure 33 Concordance lines for threatened

The actor in the case of blackmail is also occupied by ABZ: he (1.1, 2 ) and this person (1.4). The goal slot is filled by us (1.1) and me $(1.2,4)$. In 1.3, blackmail is used as a noun not as a process.

\begin{tabular}{|c|l||}
\hline \hline $\mathrm{N}$ & Concordance \\
\hline 1 & sister, and my friends. He threatened to blackmail of us. I was genuinely scared \\
\hline 2 & $\begin{array}{c}\text { where I live, school name) to try and blackmail me into coming to his house. } \\
\text { and he got all defensive. He deleted his blackmail and messages to make it }\end{array}$ \\
\hline 4 & \begin{tabular}{c} 
see me again. This person continued to blackmail me for days that made my life \\
\hline
\end{tabular}
\end{tabular}

Figure 34 Concordance lines for blackmail

The process ruin is used in the context of blackmail since ABZ threatens his victims to ruin their lives or their relations with others. The goal of the process is 'my life' (1.1), 'your lives' (1.2), 'my friendship' (1.3), and 'my reputation' (1.4). In line 1, the victim is scared that ABZ will manage to convince her relations of the truth of the false things being said about her which would eventually ruin her life. In line 2 , the victim is reporting ABZ's threat to her and her friends that 'I'll photoshop your faces and ruin your lives'. In line 3, the victim reflects that ABZ wants to ruin her friendship with her best friend while in line 4 the victim is lamenting that $\mathrm{ABZ}$ and his group of friends want to ruin her reputation. 
Analysing the discursive strategies in the narratives of victims of an Egyptian sex predator: a corpus-assisted Discourse Historical approach Dr Wesam M. A. Ibrahim

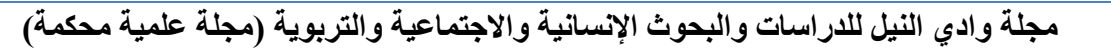

\begin{tabular}{|c|c|}
\hline $\mathrm{N}$ & Concordance \\
\hline 1 & his own or convince them enough to 'ruin my life even if you don't end up in \\
\hline 2 & . He's like l'll photoshop your faces And ruin your lives 69 Story Last summer \\
is obviously not true. He wanted to ruin my friendship with one of my \\
3
\end{tabular}$\quad \begin{array}{r}\text { haga takhayali they wanna ruin my reputation 34 ANON } 14 \text { OMG } \\
4\end{array} \quad$\begin{aligned} by his older brother I also don't want to ruin his brother's reputation 45 ANON \\
\hline 5\end{aligned}

Figure 35 Concordance lines for ruin

Finally, a group of processes relate to communication via social media. It includes the processes texted, blocked, send and messaged. The process texted has ABZ as the actor in almost all concordance lines expressed with the pronoun he $(1.1,2,4,5,8,10$, $11,12,13,14,15,16,18)$, this guy $(1.3,9)$, his name followed by asshole (1.6), and his first name (1.17). The agent position is occupied by a victim in line 7 with the subject $I$ referring to the victim who texted $A B Z$ to ask him why he did this to her specifically; and by a victim's boyfriend texting to ask ABZ not to bother the victim (1.11). ABZ occupies the goal position in these two cases. In the rest of the concordances, the goal is occupied by the victims or their relations: the former expressed by the pronoun me $(1.1,2,4,6,9,10,12,16,17,18)$ and the latter expressed by my friends $(1.5,14)$, my best friend (1.3), her boyfriend (1.8), every single person (1.13), and my friend (1.15). 
مجلة وادي النيل للاراسات والبحوث الإنسانية والاجتماعية والتربوية (مجلة علمية محكمة)

(ISSN : 2536 - 9555)

\begin{tabular}{|c|c|}
\hline $\mathrm{N}$ & Concordance \\
\hline 1 & all my chats with Ahmed Zaki But he texted me too and kept trying to \\
\hline 2 & Then the morning of the party he texted me again and asked if I was \\
\hline 3 & Zaki, I live in El Gouna and this guy texted my best friend and I however my \\
\hline 4 & on her, but he ended up texting me He texted me multiple times on Instagram \\
\hline 5 & friend group They drug and rape girls He texted my friends older sister from \\
\hline 6 & zaki asshole at first added me on $\mathrm{fb}$ and texted me. I only answered cuz I found \\
\hline 7 & him off my social media w kolo $w$ I texted a few weeks ago cause I wanted \\
\hline 8 & leave her boyfriend but she didn't. he texted her boyfriend and told him that \\
\hline 9 & to sleep with him 62 ANON 44 This guy texted me out of no where idkk aslun \\
\hline 10 & refused then we both broke up. He later texted me telling me that his friends \\
\hline 11 & HIM! I told my bf the story and he texted this motherfucker to tell him to \\
\hline 12 & wrong bas once again, I was 14 . He texted me the next day \& he kept \\
\hline 13 & that I won't have sex with him. He texted every single person I go to \\
\hline 14 & weirded out by him because he'd texted my friends before coming so I \\
\hline 15 & why and I then discovered that he had texted my friend. He even requested my \\
\hline 16 & this awareness[032]. 30 ANON 18 He texted me too in May. I don't even know \\
\hline 17 & Hii hope all is good, Ahmed basically texted me initiating a conversation \\
\hline 18 & where I live. A couple of days later he texted me again asking me why girls \\
\hline
\end{tabular}

Figure 36 Concordance lines for texted

After being verbally or physically abused by ABZ, the victims tend to end their relations with him using the blocking function characteristic of mobile phones and social media apps. It is no wonder that the actor in all concordance lines for the process blocked is always occupied by the victims expressed by the pronoun $I(1.1,2,3,5,6,7,10,11,12,13,14,15,20,21)$, girls (1.4), my friend $(1.8)$, and she $(1.9,16,19)$. Note that in the concordance lines where the actor is occupied by my friend or she the first-person narrator of the story is not the victim herself but a friend of hers reporting the victim's story with ABZ. The goal position in most concordances is occupied by the third-person object pronoun him referring to ABZ $(1.2,3,4,5,6,7,8,9,10,11$, $13,14,15,16,18,19,20,21)$ or the possessive structure his number (ABZ's phone number) $(1.1,12)$. It should be noted that in 
Analysing the discursive strategies in the narratives of victims of an Egyptian sex predator: a corpus-assisted Discourse Historical approach Dr Wesam M. A. Ibrahim

مجلة و ادي النيل للاراسات والبحوث الإنسانية والاجتماعية والتربوية (مجلة علمية محكمة)

1.17 blocked is not used as a process but as a participial adjective modifying the victim's contact list.

\begin{tabular}{|c|c|}
\hline $\mathrm{N}$ & \\
\hline 1 & $m$ \\
\hline 2 & \multirow{20}{*}{$\begin{array}{l}\text { protecting their reputation. Right before I blocked him he was trying to force sex } \\
\text { him not to speak to me anymore and blocked him. He then spent weeks } \\
\text { me again asking me why girls always blocked him so I asked why and I then } \\
\text { and I however my best friend instantly blocked him so he didn't get the chance } \\
\text { (I didn't) then he got angry and said if I blocked him he'd find out where I live } \\
\text { I was literally traumatized. Anyway I blocked him and deactivated all my } \\
\text { hurt me if I try to leave, my friend blocked him off my social media w kolo } \\
\text { my room I told her everything and she blocked him. Or post it l'm not scared of } \\
\text { di nemret mamtek w msh 3arfa eh I blocked him w fedel ycall me idkk gab } \\
\text { me to go over to his house! When I blocked him, he made other accounts } \\
\text { hashoofek tany. Right when I left I blocked [015]his number so he wouldn't } \\
\text { be better .. I told him to fuck off and blocked him... I will try to find the } \\
\text { w meshyt w I didn't reply again and I blocked him. } 10 \text { ANON } 35 \text { Hey, when I } \\
\text { days that made my life a fucking hell. I blocked him everywhere and have been } \\
\text { w hwa akeed gery 3shan babaha she blocked him everywhere He's older than } \\
\text { block w I still have his number kn my blocked list 3ala wp } 25 \text { ANON } 41[026] \\
\text { he wouldn't do that to others then blocked him. } 26 \text { ANON } 40 \text { I know this } \\
\text { w kan beyo3od yeb3atlaha fa she blocked him mn kol heta so when he } \\
\text { my friends before coming so I just blocked him as soon as he tried hahaha } \\
\text { wants me in his house but I refused and blocked him immediately (please }\end{array}$} \\
\hline 3 & \\
\hline 4 & \\
\hline 5 & \\
\hline 6 & \\
\hline 7 & \\
\hline 8 & \\
\hline 9 & \\
\hline 1 & \\
\hline 11 & \\
\hline 12 & \\
\hline 13 & \\
\hline 14 & \\
\hline 15 & \\
\hline 16 & \\
\hline 17 & \\
\hline 18 & \\
\hline 10 & \\
\hline 2 & \\
\hline & \\
\hline
\end{tabular}

Figure 37 Concordance lines for blocked

In relation to this group of processes, other keywords also relate to the context of social media and communication (see Table 11). This is because most events involving ABZ and the victims include communication by phones or social media apps. 
(ISSN : 2536 - 9555)

\begin{tabular}{|c|c|c|c|c|c|c|c|}
\hline $\mathbf{N}$ & Key word & Freq. & $\%$ & $\begin{array}{l}\text { RC. } \\
\text { Freq. }\end{array}$ & $\begin{array}{c}\text { RC. } \\
\%\end{array}$ & Keyness & $\mathbf{P}$ \\
\hline 32 & TEXTING & 10 & 0.075631522 & $\mathbf{0}$ & & 87.65116119 & $5.18027 \mathrm{E}-15$ \\
\hline 49 & MESSAGES & 12 & 0.090757824 & 16 & & 67.34243011 & $2.15823 E-14$ \\
\hline 60 & INSTAGRAM & 7 & 0.052942067 & 0 & & 61.35424423 & $3.90855 E-14$ \\
\hline 72 & WHATSAPP & 6 & 0.045378912 & 0 & & 52.58890152 & $1.24546 \mathrm{E}-13$ \\
\hline 98 & SCREENSHOTS & 5 & 0.037815761 & $\mathbf{0}$ & & 43.8237114 & $8.43846 \mathrm{E}-13$ \\
\hline 119 & FACEBOOK & 4 & 0.030252609 & 0 & & 35.05867004 & $6.7423 \mathrm{E}-10$ \\
\hline 124 & CHAT & 6 & 0.045378912 & 7 & & 34.82007217 & $6.91559 \mathrm{E}-10$ \\
\hline 147 & PHONE & 9 & 0.06806837 & 53 & & 28.85396385 & $7.51213 \mathrm{E}-08$ \\
\hline
\end{tabular}

Table 11 communication and social media in the keywords

Most of the material processes discussed above have ABZ as the active agent and the victims as the passive objects being acted upon, except in the case of the process blocked which can be seen as a kind of defensive strategy.

Examining the keywords and their concordances in the light of perspectivation, nomination and predication reveals the way ABZ, his actions, and his victims are constructed in the narratives. These narratives, which are presented as factual accounts of real-life incidents between the narrators (or their friends in some cases) and the sexual perpetrator (ABZ), reflect the perspective of sexual abuse and/or harassment victims. The nomination of ABZ shows how he is perceived as a nice normal person in the beginning of a relationship and then as a creepy, abnormal criminal after the narrator has been abused by him whether verbally or physically. The material processes construct the male abuser as the active agent and the female victims as acted upon. The mental processes, on the other hand, give access to the victim's inner feelings and perception, and hence, motivate readers to identify and sympathise with the victims. 
Analysing the discursive strategies in the narratives of victims of an Egyptian sex predator: a corpus-assisted Discourse Historical approach Dr Wesam M. A. Ibrahim مجلة وادي النيل للاراسات والبحوث الإنسانية والاجتماعية والتربوية (مجلة علمية محكمة)

\section{Conclusion}

This study has tackled a very sensitive issue and explored a kind of narrative probably never seen in Egypt before. The publication of these narratives on social media is likely to cause a change in Egyptian culture. This has already started to happen with 10 girls of the victims filing official complaints against ABZ to the Prosecution Council ${ }^{16}$. Their initiative can be seen as a result of the power of social media which were flooded by allegations against ABZ, urging girls to come forward and speak out. In a very short time, the situation has developed and expanded even more widely with many girls and women posting stories and videos about their experiences of sexual harassment and assault ${ }^{17}$. The courage of

${ }^{16}$ https://m.facebook.com/story.php?story fbid $=673268590195725 \& \mathrm{id}=$ $1934175130213078 \&$ sfnsn $=$ wa\&d $=$ w\&vh $=\mathrm{e}$

https://www.bbc.com/arabic/middleeast-53333266

https://www.shorouknews.com/news/view.aspx?cdate $=07072020 \& \mathrm{id}=1 \mathrm{~d}$ 32d72d-caa7-483b-aaee-28f2e46663c7

https://www.albayan.ae/one-world/accidents/2020-07-07-1.3905815

https://www.albawabhnews.com/4078612

https://m.facebook.com/story.php?story fbid $=597023874559892 \& \mathrm{id}=11$ $1028247341137 \&$ sfnsn=wa\&d=w\&vh=e

https://m.facebook.com/story.php?story_fbid=4493654607314911\&id=2 $30322504261001 \&$ sfnsn $=$ wa\& $d=w \& v h=e$

${ }^{17}$ An example is the case of a girl who has been raped by her classmate two weeks before her wedding in 2018. Her marriage was cancelled and later she realized that she was pregnant. She gave birth to a girl and the aggressor refused to marry her or acknowledge his daughter. She filed a legal case but the aggressor's family have threatened anyone who comes forward to give witness and have hidden the aggressor. After covering her story in the social media and TV channels, many lawyers volunteered to stand by her and re-open her case.

https://www.facebook.com/watch/?v=279430686450855

https://www.youtube.com/watch?v=ZvNEXFAuBJU

https://www.youtube.com/watch? $v=$ DboMT_LrgQ

https://www.youtube.com/watch? $\mathrm{v}=\mathrm{oCwflFNHiiY}$ 
(ISSN : 2536 - 9555)

Egyptian women to recount on social media stories about being exposed to sexual assault reflects what Klosterman described as 'the heart of the concept of breaking silence really seems to be illuminating community denial and creating a context of true freedom of speech for women, of true self-presentation' (Klosterman, 1997: 247).

What Egypt is currently witnessing, at the time of writing, can be considered a shift in culture, with a growing public awareness and a tendency not to blame the victim but rather to encourage women and girls to expose all incidents of sexual harassment and/or assault. The aggressors should be held 100\% responsible for their sexual violence and their crimes should not be excused by the style of dress or personal history of the victims. This current awakening and movement of Egyptian women, encouraged by social media, may consequently lead to a reduction in the frequency of sexual misconduct since it is more likely that aggressors accused of physical or internet sexual harassment will be reported and held accountable before the Prosecution Council and under the courts of law.

\section{References}

Alsaadawi, Nawal. 2015. The Hidden Face of Eve ( ${ }^{\text {rd }}$ edn). London: Zed Books Ltd.

Baker, Paul. 2006. Using Corpora in Discourse Analysis. London: Continuum.

Baker, Paul and Tony McEnery. 2005. 'A corpus-based approach to discourses of refugees and asylum seekers in UN and newspaper texts'. Journal of Language and Politics 4(2), 197-226.

Baugh, John. 2018. 'Linguistic Harassment'. In Linguistics in Pursuit of Justice, edited by John Baugh, 134-150. Cambridge: Cambridge University Press. doi:10.1017/9781316597750.010 
Analysing the discursive strategies in the narratives of victims of an

Egyptian sex predator: a corpus-assisted Discourse Historical approach Dr Wesam M. A. Ibrahim

مجلة وادي التيل للاراسات والبحوث الإنسانية والاجتماعية والتربوية (مجلة علمية محكمة)

Caldas-Coulthard, Carmen Rosa and Malcolm Coulthard. 1996. Texts and Practices: Readings in Critical Discourse Analysis. London and New York: Routledge.

Coupland Nikolas and Justine Coupland. 1997. 'Discourses of the unsayable: Death-implicative talk in geriatric medical consultations'. In Silence: Interdisciplinary Perspectives, edited by Adam Jaworski, 117-52. Berlin and New York: Mouton de Gruyter.

Fairclough, Norman. 1992. Discourse and Social Change. Cambridge: Polity Press.

Fairclough, N. 2010. Critical discourse analysis: the critical study of language. Harlow, England; New York: Longman.

Fairclough, Norman and Ruth Wodak. 1997. 'Critical Discourse Analysis Overview'. In Discourse Studies: A Multidisciplinary Introduction (Vol 2), edited by Teun Van Dijk, 258-284. London: Sage.

Fairclough, Norman, Jane Mulderrig and Ruth Wodak. 2011. 'Critical Discourse Analysis'. In Discourse studies: a multidisciplinary introduction ( $2^{\text {nd }}$ ed), edited by Teun A. van Dijk, 357-378. Thousand Oaks, Calif: Sage Publications.

Fitzgerald, Louise F. and Lilia M. Cortina. 2017. 'Sexual Harassment in Work Organizations: A View From the Twenty-First Century'. In APA Handbook of the Psychology of Women (Vol 2): Perspectives on Women's Private and Public Lives, edited by Cheryl B. Travis and Jacquelyn W. White. APA. http://www.apa.org/pubs/books/4311534 aspx?tab=2.

Fitzgerald Louise F., Sandra L. Shullman, Nancy Bailey, Margaret Richards, Janice Swecker, Yael Gold, Mimi Ormerod, and Lauren Weitzman. 1988. 'The incidence and dimensions of 
مجلة وادي النيل للاراسات والبحوث الإنسانية والاجتماعية والتربوية (مجلة علمية محكمة)

(ISSN : 2536 - 9555)

sexual harassment in academia and the workplace'. Journal of Vocational Behavior 32(2), 152-175.

Gelfand Michelle J., Louise F. Fitzgerald and Fritz Drasgow. 1995. 'The structure of sexual harassment: A confirmatory analysis across cultures and settings'. Journal of Vocational Behavior 47(2), 164-177.

Groth, Nicholas. 1979. Men Who Rape: The Psychology of the Offender. New York: Plenum Press.

Haddad, Mais. 2017. Victims of Rape and Law: How the Arab World Laws protect the Rapist not the Victim, JURIST Dateline, May. 2017, http://jurist.org/dateline/2017/05/victims-of-rape-and-lawhow-the-arab-world-laws-protect-the-rapist-not-thevictim.php

Hajdin, Mane. 1994. 'Sexual Harassment in the Law: The Demarcation Problem'. Journal of Social Philosophy 25, 102-22.

Hajdin, Mane. 1997. 'Sexual Harassment and Negligence'. Journal of Social Philosophy 28(1), 37-53.

Halliday, Michael A. K. 1994. An Introduction to Functional Grammar. London: Edward Arnold.

Holland Kathryn J. and Lilia M Cortina. 2016. 'Sexual Harassment: Undermining the Wellbeing of Working Women'. In Handbook on well-being of working women, edited by Mary L. Connerley and Jiyun Wu, 83-101. https://doi.org/10.1007/978-94-017-9897-6.

Holmes, Ronald M. and Stephen T. Holmes. 2002. Profiling Violent Crimes: An Investigative Tool. Thousand Oaks: Sage.

Hosseinmardi, Homa, Sabrina Arredondo Mattson, Rahat Ibn Rafiq, Richard Han, Qin Lv and Shivakant Mishr. 2015. 'Prediction of cyberbullying incidents on the instagram social network'. ArXiv, abs/1508.06257. 
Analysing the discursive strategies in the narratives of victims of an Egyptian sex predator: a corpus-assisted Discourse Historical approach Dr Wesam M. A. Ibrahim مجلة وادي النيل للاراسات والبحوث الإنسانية والاجتماعية والتربوية (مجلة علمية محكمة)

Jancarikova, Renata. 2013. 'Simplification in the British press: Binary oppositions in crime reports'. Discourse and Interaction, 6 (2), 15-28.

Johnson, Paula A., Sheila E. Widnall, and Frazier F. Benya (eds). 2018. Sexual Harassment of Women: Climate, Culture, and Consequences in Academic Sciences, Engineering, and Medicine. Washington (DC): National Academies Press.

Jeffries, Lesly. 2006. Discovering language: The structure of modern English. Basingstoke: Palgrave Macmillan.

Jeffries, Lesly. 2010. Critical Stylistics. The Power of English. Basingstoke: Palgrave Macmillan.

Jeffries, Lesly and Dan McIntyre. 2010. Stylistics. Cambridge: Cambridge University Press.

Kennedy, Helena. 1992. Eve Was Framed: Women and British Justice. London: Vintage.

Klosterman, Ellen. 1997. The Music She Hears: Point of View and Technique in Women's Writing about Childhood Sexual Abuse. Ohio: Bowling Green State University.

Konik Julie and Lilia M. Cortina. 2008. 'Policing gender at work: Intersections of harassment based on sex and sexuality'. Social Justice Research. https://doi.org/10.1007/s11211008-0074-z.

Leskinen Emily A., Lilia M Cortina and Dana B Kabat. 2011. 'Gender harassment: Broadening our understanding of sexbased harassment at work'. Law and Human Behavior 35(1), 25-39. https://doi.org/10.1007/s10979-010-9241-5.

Locke, Terry. 2004. Critical discourse analysis. London and New York: Continuum. 
(ISSN : 2536 - 9555)

Machin, David and Andrea Mayr. 2012. How to Do Critical Discourse Analysis: A Multimodal Introduction. London: Sage.

MacKinnon, Catherine A. 1989. Toward a Feminist Theory of the State. Cambridge MA: Harvard University Press.

Mangaonkar, Amrita, Allenoush Hayrapetian and Rajeev Raje. 2015. 'Collaborative detection of cyberbullying behavior in Twitter data'. Proceedings of the 2015 IEEE International Conference on Electro/Information Technology (EIT), 611616. https://ieeexplore.ieee.org/document/7293405

Matthews, Nancy A. 1994. Confronting Rape: The Feminist AntiRape Movement and the State. London: Routledge.

McEnery, Tony. 2006. Swearing in English: Bad Language, Purity and Power from 1586 to the Present. Psychology Press.

McEnery, Tony and Andrew Wilson. 2001. Corpus linguistics: An introduction. Edinburgh: Edinburgh University Press.

Nobata, Chikashi, Joel Tetreault, Achint Thomas, Yashar Mehdad, and Yi Chang. 2016. 'Abusive language detection in online user content'. In Proceedings of the 25th International Conference on World Wide Web (IW3C2). International World Wide Web Conferences Steering Committee, 145153. http://dx.doi.org/10.1145/2872427.2883062

Notman Malkah T. and Carol C. Nadelson. 1980. 'Psychodynamic and Life-Stage Considerations in the Response to Rape'. In The Rape Crisis Intervention Handbook, edited by McCombie S.L. Springer. Boston, MA. https://doi.org/10.1007/978-1-4684-3689-1 10

Rabelo, Verónica Caridad and Lilia M. Cortina. 2014. 'Two sides of the same coin: Gender harassment and heterosexist harassment in LGBQ work lives'. Law and Human Behavior 38(4), 378-391. 
Analysing the discursive strategies in the narratives of victims of an

Egyptian sex predator: a corpus-assisted Discourse Historical approach Dr Wesam M. A. Ibrahim

مجلة وادي النيل للاراسات والبحوث الإنسانية والاجتماعية والتربوية (مجلة علمية محكمة)

Reisigl, Martin and Ruth Wodak. 2001. Discourse and Discrimination: Rhetorics of Racism and Anti-Semitism. London: Routledge.

Reisigl, Martin and Ruth Wodak. 2009. 'The discourse-historical approach'. In Methods of critical discourse analysis ( $2^{\text {nd }}$ ed), edited by Ruth Wodak and Michael Meyer, 87-121). London: SAGE.

Rezvan, Mohammadreza, Saeedeh Shekarpour, Faisal Alshargi, Krishnaprasad Thirunarayan, Valerie L. Shalin, and Amit Sheth. 2020. 'Analyzing and learning the language for different types of Harassment'. PLOS ONE 15(4). https://doi.org/10.1371/journal.pone.0227330

Scott, Mike. 1999. WordSmith Tools Help Manual, Version 3.0. Oxford: Oxford University Press.

Seagrave, Kerry. 2013. The Sexual Harassment of Women in the Workplace, 1600-1993. Reprint edition. Jefferson, NC: McFarland.

Simpson, Paul. 1993. Language, Ideology and Point of View. London: Routledge.

Simpson, Paul. 2004. Stylistics: A resource book for students. London and New York: Routledge.

Tabbert, Ulrike. 2012. 'Crime through a corpus: The linguistic construction of offenders in the British press'. In Constructing crime: Discourse and cultural representations of crime and Deviance, edited by Christiana Gregoriou, 130-144. Basingstoke: Palgrave Macmillan.

Tabbert, Ulrike. 2016. Language and Crime: Constructing Offenders and Victims in Newspaper Reports. London: Palgrave Macmillan

Tyler, Andrea and Diana Boxer. 1996. 'Sexual harassment? Crosscultural/cross-linguistic perspectives'. Discourse and 
مجلة وادي النيل للاراسات والبحوث الإنسانية والاجتماعية والتربوية (مجلة علمية محكمة)

(ISSN : 2536 - 9555)

Society Vol.7(1),

107-133.

https://www.jstor.org/stable/42888025

van Dijk, Teun A. 1997. 'Discourse as interaction in society'. In Discourse as social interaction, edited by Teun van Dijk, 137. London: Sage.

van Dijk, Teun A. 2001. 'Critical Discourse Analysis'. In The Handbook of Discourse Analysis, edited by Deborah Schiffrin, Deborah Tannen and Heidi E. Hamilton, 352-371. Oxford: Blackwell.

van Dijk, Teun A. 2008. Discourse and context: a socio-cognitive approach. Cambridge: Cambridge University Press.

van Leeuwen, Theo. 2005. 'Typographic meaning'. Visual Communication, 4(2), 137-143. https://doi.org/10.1177/1470357205053749

van Leeuwen, Theo. 2008. Discourse and Practice: New Tools for Critical Discourse Analysis. Oxford University Press.

Weiss, Gilbert and Ruth Wodak. (Eds.). 2007. Critical discourse analysis: theory and interdisciplinarity. Basingstoke: Palgrave Macmillan.

Willig, Carla. 1999. 'Introduction: Making a difference'. In Applied discourse analysis: Social and psychological interventions, edited by Carla Willig, 1-21. Buckingham: Open University Press.

Wodak, Ruth. 1986. Language behavior in therapy groups. Berkeley: University of California Press.

Wodak, Ruth. 2001. 'The discourse-historical approach'. In Methods of critical discourse analysis, edited by Ruth Wodak and Michael Meyer, 81-115. London, Thousand Oaks: SAGE.

Wodak, Ruth. 2008. 'Introduction: terms and concepts'. In Qualitative discourse analysis in the social sciences, edited by Ruth Wodak and Michal Krzyżanowski, 1-42. 
Analysing the discursive strategies in the narratives of victims of an Egyptian sex predator: a corpus-assisted Discourse Historical approach Dr Wesam M. A. Ibrahim مجلة وادي النيل للاراسات والبحوث الإنسانية والاجتماعية والتربوية (مجلة علمية محكمة)

Houndmills, Basingstoke, Hampshire and New York: Palgrave Macmillan.

Wodak, Ruth. 2011a. 'Complex texts: Analysing, understanding, explaining and interpreting meanings'. Discourse Studies, 13(5), 623-633. https://doi.org/10.1177/1461445611412745

Wodak, Ruth. 2011b. The discourse of politics in action: politics as usual. New York: Palgrave Macmillan.

Wodak, Ruth. 2015. 'Critical Discourse Analysis: Discourse-Historical Approach'. In The international encyclopedia of language and social interaction, edited by Karen Tracy, Cornelia Ilie and Todd Sandel, T. Chichester: John Wiley \& https://doi.org/10.1002/9781118611463.wbielsi116

Wodak, Ruth and Gilbert Weiss. 2005. 'Analyzing European Union discourses: theories and applications'. In A New Agenda in (Critical) Discourse Analysis: theory, methodology and interdisciplinarity, edited by Ruth Wodak and Paul Chilton, 121-135. Amsterdam, Philadelphia: John Benjamins.

Wodak, Ruth and Michael Meyer. 2009. 'Citical Discourse Analysis: History, Agenda, Theory and Methodology'. In Methods of Critical Discourse Analysis, edited by Ruth Wodak and Michael Meyer, 1-33. London: Sage.

Wodak, Ruth and Paul Chilton. 2005. A new agenda in (critical) discourse analysis: theory, methodology and interdisciplinarity. Amsterdam, Philadelphia: John Benjamins.

Wodak, Ruth, Rudolf de Cillia, Martin Reisigl and Karin Liebhart. 1999. The discursive construction of national identity. Edinburgh: Edinburgh University Press. 
مجلة وادي النيل للار اسات والبحوث الإنسانية والاجتماعية والتربوية (مجلة علمية محكمة)

(ISSN : 2536 - 9555)

\section{Appendix 1}

A sample of newspapers and media coverage of the 'Egyptian Predator' story.

https://www.middleeastmonitor.com/20200703-egypt-student-accusedof-over-50-sexual-crimes/

https://www.almasryalyoum.com/news/details/1994527

https://almesryoon.com/story/1306223/\%D8\%A3\%D8\%AD\%D9\%85\% D8\%AF-\%D8\%A8\%D8\%B3\%D8\%A7\%D9\%85\%D8\%B2\%D9\%83\%D9\%89-\%D9\%85\%D8\%AA\%D9\%87\%D9\%85$\% \mathrm{D} 8 \% \mathrm{AA} \% \mathrm{D} 8 \% \mathrm{AD} \% \mathrm{D} 8 \% \mathrm{~B} 1 \% \mathrm{D} 8 \% \mathrm{~B} 4-$ \%D8\%A7\%D9\%84\%D9\%81\%D8\%AA\%D9\%8A\%D8\%A7\%D8\%AA$\% \mathrm{D} 9 \% 8 \mathrm{~A} \% \mathrm{D} 9 \% 81 \% \mathrm{D} 8 \% \mathrm{AC} \% \mathrm{D} 8 \% \mathrm{~B} 1-$ $\% \mathrm{D} 9 \% 85 \% \mathrm{D} 9 \% 81 \% \mathrm{D} 8 \% \mathrm{~A} 7 \% \mathrm{D} 8 \% \mathrm{AC} \% \mathrm{D} 8 \% \mathrm{~A} 3 \% \mathrm{D} 8 \% \mathrm{~A} 9-$ \%D9\%85\%D8\%AF\%D9\%88\%D9\%8A\%D8\%A9

https://www.alarabiya.net/ar/arab-andworld/egypt/2020/07/05/\%D8\%A7\%D $9 \% 84 \% D 9 \% 82 \% \mathrm{D} 8 \% \mathrm{~A} 8 \% \mathrm{D} 8 \%$ B6-\%D8\%B9\%D9\%84\%D9\%89\%D8\%A7\%D9\%84\%D9\%85\%D8\%AA\%D8\%AD\%D8\%B1\%D8\%B4$\% \mathrm{D} 8 \% \mathrm{~A} 8 \% \mathrm{D} 9 \% 81 \% \mathrm{D} 8 \% \mathrm{AA} \% \mathrm{D} 9 \% 8 \mathrm{~A} \% \mathrm{D} 8 \% \mathrm{~A} 7 \% \mathrm{D} 8 \% \mathrm{AA}-$ $\% \mathrm{D} 9 \% 85 \% \mathrm{D} 8 \% \mathrm{~B} 5 \% \mathrm{D} 8 \% \mathrm{~B} 1-$ \%D9\%88\%D8\%A7\%D8\%AD\%D8\%A7\%D9\%84\%D8\%AA\%D9\%87\%D9\%84\%D9\%84\%D8\%AA\%D8\%AD\%D9\%82\%D9\%8A\%D9\%82-

https://www.eremnews.com/entertainment/arts-celebrities/2270517

https://www.eremnews.com/entertainment/society/2270486

https://www.youm7.com/story/2020/7/4/\%D8\%A7\%D9\%84\%D9\%86\% D9\%8A\%D8\%A7\%D8\%A8\%D8\%A9-

\%D8\%A7\%D9\%84\%D8\%B9\%D8\%A7\%D9\%85\%D8\%A9-

$\% \mathrm{D} 8 \% \mathrm{AC} \% \mathrm{D} 8 \% \mathrm{~A} 7 \% \mathrm{D} 8 \% \mathrm{~B} 1 \% \mathrm{D} 9 \% 89-$

\%D8\%A7\%D9\%84\%D8\%AA\%D8\%AD\%D9\%82\%D9\%8A\%D9\%82$\% \mathrm{D} 9 \% 85 \% \mathrm{D} 8 \% \mathrm{~B} 9-$

\%D8\%A7\%D9\%84\%D9\%85\%D8\%AA\%D9\%87\%D9\%85-

$\% \mathrm{C} 2 \% \mathrm{AB} \% \mathrm{D} 8 \% \mathrm{~A} 3 \% \mathrm{D} 8 \% \mathrm{AD} \% \mathrm{D} 9 \% 85 \% \mathrm{D} 8 \% \mathrm{AF}-$

\%D8\%A8\%D8\%B3\%D8\%A7\%D9\%85- 
Analysing the discursive strategies in the narratives of victims of an

Egyptian sex predator: a corpus-assisted Discourse Historical approach Dr Wesam M. A. Ibrahim

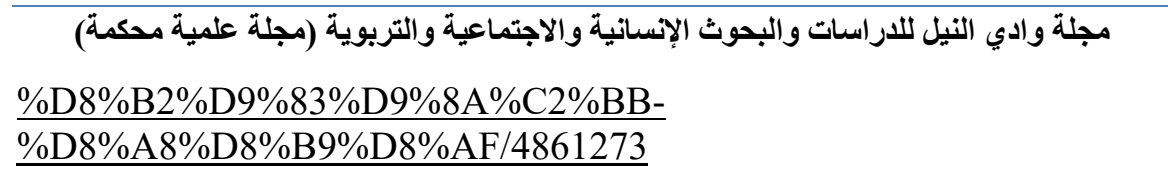

https://akhbarelyom.com/news/newdetails/3075743/1/\%D8\%A7\%D9\%8 4\%D9\%86\%D9\%8A\%D8\%A7\%D8\%A8\%D8\%A9\%D8\%AA\%D8\%A8\%D8\%AF\%D8\%A3\%D8\%A7\%D9\%84\%D8\%AA\%D8\%AD $\%$ D9\%82\%D9\%8A\%D9\%82 \%D8\%A7\%D8\%AA-\%D9\%85\%D8\%B9\%D8\%A7\%D9\%84\%D9\%85\%D8\%AA\%D9\%87\%D9\%85$\% \mathrm{D} 8 \% \mathrm{~A} 3 \% \mathrm{D} 8 \% \mathrm{AD} \% \mathrm{D} \%$ \%5\%D8\%AF\%D8\%A8\%D8\%B3\%D8\%A7\%D9\%85-\%D8\%B2\%D9\%83\%D9\%8A

https://www.layalina.com/\%D8\%B5\%D9\%88\%D8\%B1\%D8\%AA\%D8\%B9\%D8\%B1\%D9\%81\%D9\%83\%D9\%85\%D8\%B9\%D9\%84\%D9\%89-\%D9\%84\%D9\%84\%D8\%A7\%D9\%81\%D8\%B6\%D8\%A9-\%D8\%A7\%D9\%84\%D8\%AA\%D9\%8A$\% \mathrm{D} 8 \% \mathrm{AA} \% \mathrm{D} 8 \% \mathrm{~B} 5 \% \mathrm{D} 8 \% \mathrm{AF} \% \mathrm{D} 8 \% \mathrm{~B} 1 \% \mathrm{D} 8 \% \mathrm{AA}-$ $\% \mathrm{D} 8 \% \mathrm{~A} 7 \% \mathrm{D} 9 \% 84 \% \mathrm{D} 8 \% \mathrm{AA} \% \mathrm{D} 8 \% \mathrm{~B} 1 \% \mathrm{D} 9 \% 86 \% \mathrm{D} 8 \% \mathrm{AF}-$ $\% \mathrm{D} 8 \% \mathrm{~A} 8 \% \mathrm{D} 8 \% \mathrm{~B} 9 \% \mathrm{D} 8 \% \mathrm{AF}-$ \%D9\%82\%D8\%B5\%D8\%AA \%D9\%87\%D8\%A7-\%D9\%85\%D8\%B9\%D8\%A3\%D8\%AD\%D9\%85\%D8\%AF- 


\section{مجلة وادي النيل للاراسات والبحوث الإنسانية والاجتماعية والتربوية (مجلة علمية محكمة)}

(ISSN : 2536 - 9555)

\%D8\%A8\%D8\%B3\%D8\%A7\%D9\%85-\%D8\%B2\%D9\%83\%D9\%8A$\underline{365290 . h t m l}$

https://alwafd.news/\%D9\%85\%D9\%8A\%D9\%80\%D8\%AF\%D9\%8A\% D8\%A7/3062770-\%D9\%81\%D9\%8A\%D8\%AF\%D9\%8A\%D9\%88-

\%D8\%A3\%D9\%88\%D9\%84-

\%D8\%AA\%D8\%B9\%D9\%84\%D9\%8A\%D9\%82-\%D9\%85\%D9\%86-

$\% \mathrm{D} 9 \% 88 \% \mathrm{D} 8 \% \mathrm{~A} 7 \% \mathrm{D} 9 \% 84 \% \mathrm{D} 8 \% \mathrm{AF}-$

$\% \mathrm{D} 8 \% \mathrm{~A} 3 \% \mathrm{D} 8 \% \mathrm{AD} \% \mathrm{D} 9 \% 85 \% \mathrm{D} 8 \% \mathrm{AF}-$

\%D8\%A8\%D8\%B3\%D8\%A7\%D9\%85-\%D8\%B2\%D9\%83\%D9\%8A\%D8\%A7\%D9\%84\%D8\%B4\%D8\%A7\%D8\%A8-

\%D8\%A7\%D9\%84\%D9\%85\%D8\%AA\%D9\%87\%D9\%85-

\%D8\%A8\%D8\%A7\%D9\%84\%D8\%AA\%D8\%AD\%D8\%B1\%D8\%B4-

\%D8\%A8\%D8\%A7\%D9\%84\%D9\%81\%D8\%AA\%D9\%8A\%D8\%A7

$\% \mathrm{D} 8 \% \mathrm{AA}$ 